\title{
GNOOSISE PÄRITOLU
}

\author{
Jaan LAHE
}

Tartu Ülikooli usuteaduskond, Ülikooli 18, 50090 Tartu, Eesti; jaan.lahe@eelk.ee

Gnoosis on hilisantiikaegne religioosne liikumine, mis levis meie ajaarvamise esimestel sajanditel kristlusega samas ajaloolis-geograafilises ruumis - Vahemere ruumis. Ka fenomenoloogiliselt kuulub gnoosis kristlusega samasse religioonitüüpi - ta on lunastususund -, kuid erinevalt ristiusust on gnoosise päritolu probleem, mis põhjustab vaidlusi tänaseni. Artiklis on vaadeldud erinevaid teooriaid ja hüpoteese gnoosise religiooniloolisest päritolust antiikajast tänapäevani.

Ilmselt ei ole ühtki teist hilisantiikaegset religiooni, mille päritolust oleks nii palju hüpoteese kui antiiksest gnoosisest. Nende rohkus ja vastuolulisus näitavad, et selles osas puudub selgus, kuid me ei pääse sellest küsimusest kuidagi mööda ükskõik, kuidas me gnoosise ajalugu ka käsitleda ei püüaks. ${ }^{1}$ Küsimusele gnoosise religiooniloolisest päritolust lisandub ka gnoosise tekkeaja probleem.

13.-18. aprillini 1966 toimus Messinas (Itaalias) konverents, mis käsitles gnoosise päritolu. Konverentsi ettekanded ja diskussioonid avaldati pealkirja all "Le Origini dello Gnosticismo" 1967. aastal. Ettekanded näitavad aga, et gnoosise päritolu küsimuses puudus ka 1960. aastatel üksmeel. Sama olukord valitseb ka praegu, 37 aastat pärast Messina konverentsi, ehkki tolle ajaga võrreldes on teadlaste hulgas saavutatud nüüdseks mõnevõrra suurem konsensus.

H.-J. Schoeps ${ }^{2}$ ja R. Haardt ${ }^{3}$ jaotavad teooriad gnoosise religiooniloolisest päritolust kolme rühma: 1) teooriad, mis tuletavad gnoosise päritolu kreeka religioo-

1 Paljud uurijad on nimetanud küsimust gnoosise päritolust koguni gnoosise peaprobleemiks. Vt Drijvers, H. J. W. Die Ursprünge des Gnostizismus als religionsgeschichtliches Problem. - Rmt: Rudolph, K. (Hrsg.). Gnosis und Gnostizismus. (Wege der Forschung, CCLXII.) Darmstadt, Wissenschaftliche Buchgesellschaft, 1975, 789; Berliner Arbeitskreis für koptisch-gnostische Schriften, Die Bedeutung der Texte von Nag Hammadi für die moderne Gnosisforschung. - Rmt: Tröger, K.-W. (Hrsg.). Gnosis und Neues Testament. (Studien aus Religionswissenschaft und Theologie.) Berlin, Evangelisches Verlagsanstalt, 1973, 17; Klauck, H.-J. Die religiöse Umwelt des Urchristentums, II. Herrscher- und Kaiserkult, Philosophie, Gnosis (Kohlhammer Studienbücher Theologie, 9, 2). Stuttgart; Berlin; Köln, W. Kohlhammer, 1996, 163.

2 Schoeps, H.-J. Urgemeinde, Judenchristentum, Gnosis. Tübingen, J. C. B. Mohr (Paul Siebeck), $31-33$. 
nist ja filosoofiast; 2) teooriad, mis tuletavad gnoosise päritolu mõnest muistsest lähisida (egiptuse, mesopotaamia või iraani) usundist; 3 ) teooriad, mis tuletavad gnoosise päritolu teatud juutluse ringkondadest. Neile tuleb lisada veel teooriad, mis näevad gnoosises endiselt kristlikku hereesiat (mille tekkimisele on avaldanud otsustavat mõju kreeka filosoofia), ja teooriad, mis näevad gnoosises omapärast ja täiesti originaalset olemishoiakut (Daseinshaltung) ega ole nõus tuletama gnoosist ühestki konkreetsest usundist, ehkki möönavad, et gnoosise tekkimisele on avaldanud mõju erinevad usundid ja maailmavaated. Järgnevalt vaatleme lühidalt iga nimetatud rühma.

\section{TEOORIAD, MIS TULETAVAD GNOOSISE PÄRITOLU KREEKA RELIGIOONIST JA FILOSOOFIAST}

Juba kirikuisad Irenaeus (Adv. haer., II, 14, 2-69), Tertullianus (De preascr. haer., VII, 5) ja Hippolytus (Ref., I. Eessõna, 11) väitsid, et gnostikud on ammutanud oma õpetused vanakreeka mütoloogiast, poeesiast ning filosoofiast ja seganud need kokku ristiusu õpetustega. Ka uusplatoonik Porphyrios (Vita Plotini, 16) tuletab gnoosise päritolu kreeka filosoofiast, kuid erinevalt kirikuisadest ei väida ta, et gnostikud oleksid oma õpetusi ristiusuga seganud. Uusaja uurijatest tuletavad gnoosise päritolu kreeka mõttemaailmast (kas selle segunemisest ristiusuga või ilma) A. von Harnack, E. de Faye, F. C. Burkitt, C. Schneider ${ }^{4}$, H. Leisegang ${ }^{5}$, R. McLachlan Wilson, H.-H. Schraeder, A. Darby Nock ${ }^{6}$, E. R. Dodds ${ }^{7}$, F. Legge, R. Crahay, P. Boyanze ja Ch. Markschies. Nii seletavad A. von Harnack ${ }^{8}$ ja

3 Haardt, R. Die Gnosis. Wesen und Zeugnisse. Salzburg, Otto Müller Verlag, 1967, 16-21; Haardt, R. Gnosis. - Rmt: Sacramentum mundi. Theologisches Lexikon für die Praxis. Bd. 2. Freiburg; Basel; Wien; Herder, 1968, 480-481; Haardt, R. Zur Methodologie der Gnosisforschung. - Rmt: Tröger, K.-W. (Hrsg.). Gnosis und Neues Testament, 185-191.

4 Schneider, C. Geistesgeschichte des antiken Christentums, I. München, C. H. Beck, 1954. Schneider ütleb: "Der Geist der Gnosis ist nur griechisch und zwar überwiegend platonisch. /.../ Die Gnosis gehört in die Geschichte des Spätplatonismus als eine seiner Abzweigungen, allerdings eine sehr merkwürdige" (268).

5 Leisegang, H. Die Gnosis. Fünfte Auflage. Leipzig, Alfred Kröner Verlag, 1924. Leisegang näeb gnoosises omapärast sünteesi ("mosaiiki") kreeka ja idamaisest vaimsusest (5-6). See süntees kujunes tema arvates välja hellenismi ajastul, kui kreeklased õppisid lähemalt tundma Lähis-Ida vanu tsivilisatsioone, Lähis-Ida rahvad aga omakorda kreeka vaimulaadi. Gnoosise vorm ja vaimne struktuur on Leisegangi arvates kreeka algupära, materjal, mida gnostilised süsteemid on oma mõtete illustreerimiseks kasutanud, pärineb aga Idast (6). Orient pakkus materjali, Kreeka töötas selle läbi ja nõnda tekkiski gnoosis, mis kuulub hellenistliku vaimsuse atmosfääri (8).

6 A. Darby Nock ütleb, et gnostitsism on "a kind of Platonism run wild" (Pagels, E. The Gnostic Gospels. London, Penguin Books, 27).

7 Dodds, E. R. Pagan and Christian in an Age of Anxiety. Some Aspects of Religious Experience from Marcus Aurelius to Constantine. Cambridge, Cambridge University Press, 1965. Eesti keeles: Paganad ja kristlased ängistuse ajastul. Tõlk M. Lepajõe. Tartu, Varrak, 2003.

8 Harnack, A. Lehrbuch der Dogmengeschichte. Bd. I: Entstehung des kirchlichen Dogmas. Vierte, neu durchgearbeitete und vermehrte Auflage. Tübingen, J. C. B. Mohr (Paul Siebeck), 1909, 250. 
Ch. Markschies ${ }^{9}$ gnoosist ühe katsena tõlgendada kristlikku sõnumit kreeka filosoofia kategooriate abil. Kuid kreeka filosoofia panust gnoosise kujunemisele tunnistavad ka need teadlased, kes gnoosise päritolu kreeka filosoofiast tuletada ei püüa (K. Stürmer ${ }^{10}$, K. Rudolph ${ }^{11}$, P. Pokorny ${ }^{12}$, G. Quispel ${ }^{13}$, H.-J. Klauck ${ }^{14}$ ja K.-W. Tröger ${ }^{15}$ ).

\section{Platonism}

On väljaspool kahtlust, et kreeka mõttemaailm, mis alates Aleksander Suure vallutustest üha enam Oriendile mõju avaldas, on mõjutanud gnoosise kujunemist. Nii viitavad R. Crahay ja P. Boyanze Platonile ja orfikutele, kes oletatavasti Aleksandria Philoni kaudu andsid gnoosisele filosoofilise terminoloogia. On kujuteldamatu, et I ja II sajandi õpetused, mida me "gnoosisena" tähistame, oleks võidud formuleerida ilma hilisantiikse filosoofia mõistesüsteemi abita; viimane oli aga sügavalt Platoni poolt mõjutatud. ${ }^{16} \mathrm{Ka}$ rida teemasid on gnostilisele mõtlemisele ja varase keisririigi (I-II sajand) aegsele filosoofilisele mõtlemisele ühised: Jumal ja hing, demiurg ja tundmatu Jumal, kurja päritolu, hinge allalaskumine vaimsest maailmast ja tema tagasipöördumine oma algkodusse, hinge vangistus (saatus) ja vabadus. Platonistlikul dualismil vaimu ning mateeria, hinge ning ihu ja Jumala ning maailma vahel on suur tähtsus ka gnoosise jaoks. See on lähtepunktiks gnostilisele maailmapildile ja andnud materjali gnostilisele teoloogiale. ${ }^{17}$ Teadlastel on siiski eri arvamused, kuivõrd õigustatult võib gnostilist ihu-hinge ja mateeria-vaimu dualismi viia tagasi Platonile või tema koolkonnale. K.-W. Tröger ütleb, et platonismi suur mõju paljudele gnostikutele on väljaspool kahtlust ja tõendatud ka Nag Hammadi tekstidega. ${ }^{18}$ Ka Rudolph väidab, et II sajandi "kõrggnostilised" süsteemid, mis peaaegu eranditult tekkisid Egiptuses, on mõne prob-

9 Vt Markschies, Ch. Die Gnosis. München, Verlag C. H. Beck, 2001.

10 Stürmer, K. Judentum, Griechentum und Gnosis. - Rmt: Rudolph, K. (Hrsg.). Gnosis und Gnostizismus, $402 \mathrm{jj}$.

11 Rudolph, K. Die Gnosis. Wesen und Geschichte einer spätaniken Religion. Unverändeter Nachdruck der dritten und durchgesehnen und ergänzten Auflage. Göttingen, Wandenhoeck \& Ruprecht, 1994, 304-305.

12 Pokorny, P. Der Ursprung der Gnosis. - Rmt: Rudolph, K. (Hrsg.). Gnosis und Gnostizismus, 756.

13 Quispel, G. Gnosis. - Rmt: Vermaseren, M. J. (Hrsg.). Die orientalischen Religionen im Römerreich. Leiden, E. J. Brill, 1986, 413, 421.

14 Klauck, H.-J. Die religiöse Umwelt des Urchristentums, II, 166.

15 Tröger, K.-W. Die Gnosis. Heilslehre und Ketzerglaube. (Herder spektrum, 4952.) Freiburg; Basel; Wien; Herder, 2001, 71-72.

16 Drijvers, H. J. W. Die Ursprünge des Gnostizismus als religionsgeschichtliches Problem, 824.

17 Rudolph, K. Die Gnosis, 305.

18 Tröger, K.-W. Zum gegenwärtigen Stand der Gnosis- und Nag-Hammadi-Forschung. - Rmt: Tröger, K.-W. (Hrsg.). Altes Testament - Frühjudentum - Gnosis. Neue Studien zu "Gnosis und Bibel". Gütersloh, Güresloher Verlagshaus Gerd Mohn, 1980, 32. 
leemiasetuse kaudu koguni vahetult platonistliku filosoofiaga seotud. Küsimuses maailma ülesehitusest ja jumalaõpetuse osas on Aleksandria gnoosis olnud oluline lüli keskplatonistlikus pärimuses, mis ühendab vanemat platonismi hilisplatonismiga. ${ }^{19}$ Keskmine platonism levis meie ajaarvamise I ja II sajandi haritlaskonna laiades ringkondades ${ }^{20}$, toetus kirjutamatule, salajasele koolkondlikule traditsioonile, tegi vahet diskursiivse mõtlemise ning intuitsiooni vahel ja õpetas hinge sugulust Jumalaga. ${ }^{21}$ Gnoosise seos keskmise platonismiga väljendub näiteks käsitluses jumaliku ainulisuse üleminekust kosmose paljususeks, mida mõistetakse degradeerumisena vaimust mateeriaks ja nähakse vaimu enesevõõrdumisena. ${ }^{22}$ Keskmisest platonismist pärinevad ka gnostikute käsitlus jumalusest, kes on hea ja transtsendentne; käsitlus vaimse maailma struktuurist ${ }^{23}$ ja võib-olla ka käsitlus hingest ja tema saatusest. ${ }^{24}$ Nii oletab näiteks J. Doresse, et gnostikud võisid oma metempsühhoosi-õpetuse laenata platonismist. ${ }^{25}$ Kuid Rudolph arvab, et otsene

19 Rudolph, K. Die Gnosis, 305.

20 Samas, 305.

21 Quispel, G. Gnosis, 413.

22 Rudolph, K. Die Gnosis, 305.

23 Gnostikute kujutlus pleroma hierarhiatest meenutab väga Platoni käsitlust ideede hierahiast.

24 Enamik keskmise platonismi ideid on tuletatavad Platoni enese filosoofiast, milles religioossel ja müütilisel komponendil oli tähtis koht. Nii kohtame Platonil ideede maailma ehk tõeliselt oleva olemise maailma ja mateeria ehk mitteolemise vastandamist; käsitlust hingest kui jumalikust algest, mis on preeksistentne (Phaidon), viibis enne kehasse asumist koos jumalatega "taevatagustes paikades" (Phaidros, $250 \mathrm{C}$ ) ja suleti siis kehasse nagu vangikongi; ideed jumaluse transtsendentsusest (Politeia, VI, 509 B) ja ka väidet, et jumalus on "täiuslikult hea" (Timaios, 29 E). Kuna aga paljud Platoni doktriinid esinevad keskmises platonismis populariseeritud (= vulgariseeritud) kujul, on keskmist platonismi nimetatud ka "vulgaarplatonismiks" või "proletaarplatonismiks".

25 Doresse, J. Gnostitsism. - Rmt: Widengren, G. \& Bleeker, C. J. (toim). Historia religionum, II. Tallinn, 1988-1990 (käsikiri), 344. See esineb juba Platonil endal (Phaidon, 81 E jj). On oletatud, et Platon võis idee metempsühhoosist laenata pütaagorlastelt, kellega tal olid otsesed kontaktid (Asmus, V. Platon. (Suuri mõtlejaid.) Tallinn, Valgus, 1971, 14). Kuid kujutlus hingede taaskehastumisest oli olemas ka orfismis ja seda tunti Kreekas laiemalt. Herodotos oletas, et õpetus hingede rändamisest on laen Egiptusest (Historia, II, 123), ent seda ei peeta tõenäoliseks, sest egiptuse usundis puuduvad sellest igasugused jäljed. S. Stadnikov ütleb, et idee hinge taaskehastumisest on vastuolus egiptlaste arusaamaga inimese surmajärgsest elust. Egiptlastele oli oluline isiksuse säilimine ka pärast surma, kusjuures hing jäi ka siis seotuks oma kehaga (st muumiaga). Stadnikov ütleb, et Herodotose väite aluseks võis olla egiptlaste uskumus, et võimukad surnud võivad mõjutada siinpoolset elu, moondudes muu hulgas kõige erinevamateks inimesteks, esemeteks, loomadeks jne. Kuid need ümberkehastumised väljendasid vaid head või halba toimingut, olemata seotud inkarnatsioonide kulgemise, indiviidi muutumise või puhastumisega (Stadnikov, S. Surm ja teispoolsus Vanas Egiptuses. - Rmt: Stadnikov, S.Vana-Egiptuse kultuurilugu. Valitud artikleid, tõlkeid ja esseid. Tallinn, Kodutrükk, 1998, 177). Herodotosele on üldse omane tendents tuletada kreeka uskumusi Egiptusest või tõlgendada neid kreeka religioonist lähtudes (vt Lahe, J. Egiptuse kultused kreeka-rooma maailmas. - Tuna, 2004, 3, 10). Õpetust hinge taaskehastumisest kohtab ka muistsetel traaklastel (Herodotos. Historia, IV, 94-95) ja tõenäoliselt on kreeklased laenanud selle uskumuse Oriendist (Kõiv, M. Kreeka filosoofia ja mõttemaailma sünnist. - Akadeemia, 1990, 3, 552). 
kreeka mõju varasele gnoosisele on tõendatav ainult üksikjuhtudel, sellal kui suurem osa kreeka mõttevarast on jõudnud gnoosisesse juutluse, eriti hellenistliku juutluse filtri kaudu. ${ }^{26}$ On kindel, et kreeka mõtlemine on avaldanud mõju juutlusele. ${ }^{27}$ See mõju oli kõige tugevam diasporaas (eriti Aleksandrias, kus viiest linnaosast kaks kuulus juutidele), aga isegi Palestiina juutlust on kreeka mõtlemine tugevalt mõjutanud, nii et uuemal ajal ei tehta enam ranget vahet "hellenistliku" ja "palestiinaliku" juutluse vahel. ${ }^{28}$

Eitamata kreeka, eriti platonistliku filosoofia panust gnoosise kujunemisele, tuleks aga vastukaaluks sarnastele joontele gnoosise ja platonismi vahel rõhutada ka nende põhimõttelisi erinevusi. Nii on näiteks erinevad gnostiline ja platonistlik dualism. Seda erinevust, mida märkas juba Plotinos, on uusaja teadlastest rõhutanud eriti Hans Jonas. ${ }^{29}$ Nii ei kujuta mateeria (hyle), mida Platon vastandab ideedele ("vaimule"), mitte ainet, millest on valmistatud nähtava maailma asjad, vaid hoopis teatud liiki ruumi, mille tõttu inimene tajub asju teineteisest eraldatuna. ${ }^{30}$ Erinevalt gnostikutest ei väida Platon ka kusagil, et empiiriline maailm on oma olemuselt halb või et ta on tekkinud mingi jumaliku olendi languse tagajärjena. Nagu gnostikud nii kasutab ka Platon maailma loonud jumaluse kohta nimetust demiourgos (Timaios, 28 A, C, 29 A, 31 A), kuid ta ei pea jumalust halvaks, vaid hoopis heaks. ${ }^{31}$ Platon väidab, et kõike hea eesmärgi poole suunates loob jumalus maailma omaenese näo järgi (Timaios, $29 \mathrm{E})^{32}$, st kõige täiuslikuma elusolendi "ideele" vastavalt. ${ }^{33}$ Platonil ei ole maailm mitte jumalast eemaldumise tagajärg, vaid ta on hoopis ise jumalik olend, keda hingestab maailmahing. ${ }^{34} \mathrm{Ka}$ planeedid ei ole Platoni arvates kurjad olendid nagu gnoosises, sest neidki hingestab maailmahing (Timaios, 36 B). Vaatamata nendele põhimõttelistele erinevustele gnostilise "antikosmilise dualismi" ja platonistliku dualismi vahel on siiski ilmne, et viimane on avaldanud teatud mõju ka gnoosisele. ${ }^{35}$

26 Rudolph, K. Stand und Aufgaben in der Erforschung des Gnostizismus. - Rmt: Rudolph, K. (Hrsg.). Gnosis und Gnostizismus, 535-536.

27 Rudolph, K. Die Gnosis, 304.

28 Samas, 304. Kogu probleemi kohta vt Hengel, M. Judentum und Hellenismus. Studien zu ihrer Begegnung unter besonderer Berücksichtigung Palästinas bis zur Mitte des 2. Jh. s V. Chr. Durchgesehene und ergänzte Auflage. (Wissenschaftlichen Untersuchungen zum Neuen Testament, 10.) Tübingen, J. C. B. Mohr (Paul Siebeck), 1973.

Jonas, H. Gnosis und spätantiker Geist. Teil 1: Die mythologische Gnosis. Göttingen, Vandenhoeck \& Ruprecht, 1934, $41 \mathrm{jj}$.

30 Asmus, V. Platon, 31.

31 Mõistet demiourgos kasutavad Looja-Jumala kohta ka Aleksandria Philon (Opif. Mundi, 10; Mut. nom., 29) ja Uus Testament (Hb, 11, 10), kusjuures Philonil ja Heebrea kirjas ei ole demiurg kuri olend.

32 See on huvitav paralleel Gn, 1, 27-le, kus sama väidetakse inimese kohta.

33 Asmus, V. Platon, 34.

34 Samas, 79.

35 Jonas, H. Gnosis und spätantiker Geist. Teil 1, 41 jj. 


\section{Müsteeriumiusundid}

Kuid mitte kõik gnoosises ei ole filosoofiast tuletatav. Eeskätt on gnoosis siiski lunastusreligioon, millel on kokkupuutepunkte teiste antiigi lunastusreligioonidega. Viimaste puhul peab mõtlema esmajoones müsteeriumireligioonidele ${ }^{36}$, aga ka varasele kristlusele. Paljud uurijad, nagu näiteks H. Jonas ${ }^{37}$, H.-Ch. Puech ${ }^{38}$, U. Bianchi ${ }^{39}$ ja H.-M. Schenke ${ }^{40}$, on viidanud gnoosise kokkupuutepunktidele vanade kreeka või hellenistlik-orientaalsete müsteeriumidega. Näiteks taotlesid nii gnoosis kui müsteeriumiusundid üht ja sama eesmärki - inimese vabanemist saatuse (heimarmene) mõju alt. Niihästi gnoosisel kui müsteeriumiusunditel oli esoteeriline iseloom - nad olid mõeldud vaid kitsale pühendatute ringile. On ka rida praktikaid, kujutlusi ja mõisteid, mis kerkivad esile niihästi gnoosises kui müsteeriumiusundites. Nii gnoosises kui ka paljudes müsteeriumiusundites seletati saatust planeetide orjastava mõjuga inimesele. ${ }^{41}$ Lunastuse eelduseks oli nii gnoosises kui ka paljudes müsteeriumiusundites teadmine, et inimese hing on pärit jumalikust maailmast ja viibib siin vaid ajutiselt, otsekui vangis või pagenduses. Nii õpetati näiteks mitraismis (Origenes. Contra Celsum, VI, 22), et inimese hing pärineb taevasest valgusest. Inimkehasse tulles läbib ta seitse taevasfäri, millest igasühes valitseb üks planeet. Möödudes planeetidest, saab hing neilt igaltühelt mingi kehalise või hingelise omaduse. Kehast surma kaudu vabanenud hing läbib taas planeetide sfäärid ja loovutab neile üksteise järel kõik enda omadused. Seejärel pöördub hing puhtana tagasi igavesse valgusse. ${ }^{42}$

Gnoosise ja müsteeriumiusundite vaheliste kokkupuutepunktide olemasolu on endastmõistetav - gnoosis tekkis, arenes ja levis ju samas ajaloolis-geograafilises regioonis kus müsteeriumiusundidki - Vahemere ruumis - ja tema leviku kõrgaeg langeb ka ajaliselt kokku müsteeriumiusundite leviku kõrgajaga (I-III sajand pKr). Seepärast arvavad näiteks Jonas ja Puech, et müsteeriumiusundid on gnoosist

36 Müsteeriumiusundid jagatakse tavaliselt kahte rühma: 1) Kreeka rahvuslikud müsteeriumid (Demeteri ja Kore müsteerium Eleusises, Dionysose-Backhose müsteerium, Orpheuse müsteerium ja kabeiride müsteerium Samothrakel); 2) idamaised-hellenistlikud müsteeriumid (Mithra, Isise ja Osirise, Attise ja Kybele jt idamaiste jumalustega seotud müsteeriumid).

37 Jonas, H. The Gnostic Religion. The Message of the Alien God and the Beginnings of Christianity. Second edition, revised. Boston, Beacon Press, 1991, 38.

38 Drijvers, H. J. W. Die Ursprünge des Gnostizismus als religionsgeschichtliches Problem, 829.

39 Bianchi, U. Das Problem der Ursprünge des Gnostizismus. - Rmt: Rudolph, K. (Hrsg.). Gnosis und Gnostizismus, $605 \mathrm{jj}$.

40 Schenke, H.-M. Hauptprobleme der Gnosis. - Rmt: Rudolph, K. (Hrsg.). Gnosis und Gnostizismus, 590-592.

41 Kontseptsiooni planeetide orjastavast väest tunnistas alates 1 . sajandist suurem osa inimesi - olgu juudid või kristlased, gnostikud või paganad. Gnostikutel on nad archontes, Pauluse kirjas efeslastele (Ef, 6, 12) kosmokratores, hermeetikutel Seitse Valitsejat (Corpus Hermeticum, I, 9), "kelle valitsemist nimetatakse Saatuseks"; et neid kartsid nii kristlased kui ka paganad, tunnistavad Origenes (apud Eusebios. Praeparatio evangelica, 6, 11, 1) ja Augustinus (De civitate dei, 5, 1).

(Dodds, E. R. Paganad ja kristlased ängistuse ajastul, 25.)

42 Vermaseren, M. J. Hellenistlikud usundid. - Rmt: Widengren, G. \& Bleeker, C. J. (toim). Historia religionum, II. Tallinn, 1988-1990 (käsikiri), 295. 
mõjutanud. Ka Rudolph ütleb: ei ole välistatud, et jumala ja usklike ühise saatuse ümber põimunud müsteeriumipärimused leidsid tee mõnesse gnostilisse kogudusse (ofiidid, naasseenid) ja et nad üritasid realiseerida lunastust praktilis-kultuslikul teel, nagu seda taotlesid müsteeriumid. ${ }^{43}$

Bianchi $^{44}$ ja Rudolph $^{45}$ viitavad ka kokkupuutepunktidele gnoosise ja orfismi vahel. Orfiline müüt hingest on sarnane gnostilise müüdiga. Selles jutustatakse, kuidas kurjad titaanid kiskusid lõhki jumal Dionysos-Zagreuse ja neelasid ta alla. Karistuseks hukutas Zeus titaanid välgu abil. Titaanide jäänustest sündis inimene, kelles seetõttu sisalduvad nii head (Dionysose) kui halvad (titaanide) alged. Inimese hing, mis on vangistatud surelikku, on jumalikkuse kandjaks ja vajab lunastust. Sellel müüdil rajanes orfikute usupraktika, mis taotles hinge vabastamist. ${ }^{46}$ Paralleelidena orfismi ja gnoosise vahel nimetab Rudolph veel uskumust, et lunastus on mõeldud vaid valitutele; orfikutele omast askeesi ja kujutlust metempsühhoosist. ${ }^{47} \mathrm{~F}$. Legge oletab, et gnoosise juured ulatuvadki tagasi orfikute õpetuseni. ${ }^{48}$ Rudolph seevastu ütleb, et orfismi otsene mõju gnoosisele ei ole tõestatav. Tema arvates võib siin rääkida üksnes üldistest kokkulangevustest käsitluses hinge saatusest. ${ }^{49}$ Põhilise argumendina nimetab Rudolph, et orfiline müüt pärineb oma täielikul kujul alles III sajandist. ${ }^{50}$ Müsteeriumiusundite otsesed mõjud gnoosisele on üldse harva tõestatavad. Nii jutustab kirikuisa Epiphanios (Panarion, 37, 5, 6-8) ofiidide maoaustamisrituaalist. Ofiidid olevat austanud elusat madu ja asetanud tema ümber erilised pühade ajal kasutatavad leivakesed, et madu neid sööks. Epiphanios näeb selles rituaalis armulaua kuratlikku imitatsiooni (!), kuid Rudolph oletab, et pigem on siin tegemist mingi vanakreeka või hellenistliku salakultuse mõjuga. ${ }^{51}$ Ka Doresse arvab, et see rituaal läheb tagasi vanade müsteeriumideni. ${ }^{52}$ Vanades kreeka müsteeriumides sümboliseeris madu maajumalust ja viljakust. Gnostikud tegid temast aga ilmutusetooja ja kõrgema Jumala hääletoru. ${ }^{53}$ On võimalik, et gnostikud kohandasid müsteeriumirituaale selleks, et võita endale nende kaudu poolehoidjaid inimeste hulgast, kes järgisid müsteeriumiusundeid. Kuivõrd oskuslikult kasutasid gnostikud teiste usundite pärandit enda huvides, näitab kujukalt manihheismi ajalugu. ${ }^{54}$ Selles avaldub gnoosise "parasiteeriv iseloom", millele on juhtinud tähelepanu Bianchi ja Rudolph. ${ }^{55}$

43 Rudolph, K. Die Gnosis, 306.

44 Bianchi, U. Das Problem der Ursprünge des Gnostizismus, 605 jj.

Rudolph, K. Die Gnosis, 306.

Irmscher, J. (koost). Antiigileksikon. Tallinn, Valgus, 1985, 396.

Rudolph, K. Die Gnosis, 306.

Legge, F. Forerunners and Rival of Christianity. Edinburgh, T. \& T. Clarck, 1964, 146 jj.

Rudolph, K. Die Gnosis, 306.

Samas, 306.

Samas, 256.

52 Doresse, J. Gnostitsism. - Rmt: Widengren, G. \& Bleeker, C. J. (toim). Historia religionum, II, 355 .

53 Rudolph, K. Die Gnosis, 255-256.

54 Asmussen, J. P. Manihheism. - Rmt: Widengren, G. \& Bleeker, C. J. (toim). Historia religionum, II, 375-376.

55 Drijvers, H. J. W. Die Ursprünge des Gnostizismus als religionsgeschichtliches Problem, 812. 
Müsteeriumiusundite ja gnoosise vahel on aga ka rida põhimõttelisi erinevusi. H.-M. Schenke ütleb, et müsteeriumiusundite ja gnoosise põhierinevus seisneb selles, et kui müsteeriumiusundite järgi on lunastus inimese jumalikustumine, inimese saamine kellekski, kes ta varem ei olnud, siis gnoosises on lunastus inimese taasjumalikustumine (Wieder-Gott-Werden des Menschen): inimene saab gnoosise kaudu selleks, kes ta algselt oli ja õigupoolest põhimõtteliselt alati on. ${ }^{56}$

Kokkuvõtteks tuleb öelda, et kreeka religiooni ja filosoofia mõjud gnoosisele on väljaspool kahtlust, aga mitte kõik gnoosises ei ole tuletatav kreeka mõttemaailmast. Gnoosises on ka palju elemente, mis on orientaalset päritolu, aga enamik gnoosise müüte ja mõisteid on "topeltpalgega" - nad on üheaegselt nii kreekalikud kui orientaalsed ${ }^{57}$, nii et kreeka ja orientaalseid mõjusid gnoosises on väga raske eristada.

\section{TEOORIAD, MIS TULETAVAD GNOOSISE PÄRITOLU MUINASIDA USUNDITEST}

Juba XVIII sajandi õpetlased C. F. W. Walch, J. D. Michaelis ja J. L. Mosheim otsisid gnoosise juuri Oriendist. XIX sajandi lõpul ja XX sajandi algul jätkas nende liini saksa religioonilooline koolkond (K. Kessler, W. Anz, H. Gunkel, W. Bousset, H. Gressmann, R. Reitzenstein), seejärel Rudolf Bultmann ja tema koolkond.

\section{Babüloonia usund}

Kõigepealt otsis religioonilooline koolkond gnoosise juuri Babülooniast. Nii väitsid $\mathrm{Kessler}^{58}$ ja Anz ${ }^{59}$, et enamikus gnostilistest süsteemidest on keskne teema hinge ülestõusmine (der Aufstieg der Seele): hing, kes on varustatud paroolidega seitsme planeedi valvuritele, rändab läbi taevaste. Kessler ja Anz oletasid täiesti õigesti, et nende valvurite prototüüpideks on vanababüloonia usundi seitse planetaarjumalat ${ }^{60}$, ja viisid gnostikute kontseptsiooni seitsmest arhondist tagasi babüloonia astraalreligiooni juurde. Kuigi seitsmele arhondile leidub tõepoolest täpne paralleel mesopotaamia usundis ${ }^{61}$, on Kessleri ja Anzi teooriat hiljem palju kriti-

56 Schenke, H.-M. Hauptprobleme der Gnosis, 590-591.

57 Schoeps, H.-J. Urgemeinde, Judenchristentum, Gnosis, 33; Stürmer, K. Judentum, Griechentum und Gnosis, $387 \mathrm{jj}$.

58 Kessler, K. Über Gnosis und altbabylonische Religion. - Rmt: Verhandl. d. 5. Orientalistenkongr. Berlin, 1882, $288 \mathrm{jj}$.

59 Anz, W. Ursprung des Gnostizismus. Leipzig, 1897.

60 Šamaš - Päike, Sin - Kuu, Nabu - Merkuur, Ištar - Veenus, Nergal - Marss, Marduk - Jupiter, Ninurta - Saturn.

61 Ei ole selge, kas gnostikud laenasid kujutluse seitsmest planetaarjumalusest babüloonia usundist otse või hellenistliku sünkretismi vahendusel, milles babüloonia elementidel oli oluline roll (Kasemaa, K. De origine et theologia mandaeorum. Mandalasist ja manda usundi gnostilisest lunastusõpetusest. Magistriväitekiri. Palamuse, 1975 (käsikiri), 50, 54). 
seeritud. Selle teooria vastu väidab Puech: hinge ülestõusmise teema puudub osas gnostilistest süsteemidest; mesopotaamia usundi mõju ei olnud meie ajaarvamise algul enam kuigi suur ja et erinevalt gnoosisest olid babüloonia astraaljumalad kõrgemad jumalad ning nad ei olnud oma loomult kurjad. ${ }^{62}$ Kessleri ja Anzi teooriat püüdis täiendada Wilhelm Bousset. ${ }^{63}$ Bousseti arvates tuleb otsida gnoosise juuri niihästi babüloonia kui pärsia usundist (zoroastrismist). Bousset väidab, et gnostikute seitse arhonti pärinevad küll babüloonia astraalreligioonist, kuid muutusid deemonlikeks olenditeks zoroastristliku dualismi mõjul. ${ }^{64}$ Nende degradeerumist seletab Bousset aga ajalooliselt: degradeerumine olevat toimunud pärast seda, kui pärslased alistasid Babüloonia (539 eKr). Alistatud rahva jumalad muudeti deemonlikeks olenditeks ja allutati pärsia peajumalale Ahura Mazdale. Viimane võib Bousseti arvates olla gnostikute tundmatu ülemjumal. ${ }^{65}$ Peale seitsme arhondi leiab Bousset babüloonia usundist prototüüpe veel teistelegi gnostilise mütoloogia tegelastele. Nii peab ta gnostilise jumaliku naisolendi (Sophia) prototüübiks babüloonia emajumalatari Ištari. ${ }^{66}$ Babüloonia müüdis laskub Ištar allilma, et vabastada sealt oma armastatu Tammuz. Ta siseneb allilma läbi seitsme värava. Gnostilises müüdis laskub "Taevane Ema" (või mõni teine jumalik naisolevus) maailma (= gnostikuile allilm), et lunastada valituid. Seejuures läbib ta seitse planeetide sfääri. Nende kahe müüdi fenomenoloogiline sarnasus on lihtsalt hämmastav, kuid ei ole võimalik tõestada, et gnostikud oleksid oma lunastusmüüdi Babülooniast laenanud.

Kokkuvõtteks tuleb öelda, et mesopotaamia usund on avaldanud mõju pea kõigile lähisida usunditele. Mesopotaamia usundi mõjud on tugevad iisraeli usundis $^{67}$, aga neid võib täheldada ka kreeka-rooma usundis, varases kristluses (Johannese ilmutusraamatus) ja islamis. ${ }^{68}$ Pole siis ime, et mesopotaamia usundi mõjusid võib leida ka gnoosises, mis kuulub samuti Vahemere ruumi usundite hulka. Kuigi babüloonia usundi mõjud gnoosises on ilmsed, on neil gnoosise kui terviku seisukohalt siiski suhteliselt tagasihoidlik koht. Nii ei saa näiteks õpetust seitsmest arhondist pidada gnoosise põhiõpetuseks, sest on süsteeme, milles see puudub. Gnoosise põhiõpetused (dualism, idee lunastavast tunnetusest ja jumalikust "sädemest" inimeses jne) ei ole babüloonia usundist tuletatavad ja seepärast võib väita, et hüpotees gnoosise mesopotaamia algupärast on mõjutatud XIX sajandi lõpul ja XX sajandi algul teaduses moes olnud panbabülonismist. ${ }^{69}$ Tänapäeval ei leidu enam uurijaid, kes püüaksid gnoosise päritolu tuletada babüloonia usundist.

62 Puech, H. Ch. Das Problem des Gnostizismus, 337.

63 Bousset, W. Hauptprobleme der Gnosis. (Forschungen zur Literatur des Alten und Neuen Testaments, 10.) Neudruck der 1. Auflage von 1907. Göttingen, Vandenhoeck \& Ruprecht, 1973.

66 Samas, $11 \mathrm{jj}$.

67 Römer, W. H. Ph. Vana-Mesopotaamia usund. - Rmt: Widengren, G. \& Bleeker, C. J. (toim). Historia religionum. Tallinn, 1988 (käsikiri), 169-170.

68 Samas, 171.

69 Lahe, J. Gnoosis ja algkristlus. 2., parandatud ja täiendatud trükk. Tallinn, Kodutrükk, 93. 


\section{Egiptuse usund}

Võrreldes babüloonia-teooriaga on teoorial gnoosise egiptuse päritolust olnud vähem pooldajaid. M. E. Amelineau üritas tõestada gnoosise pärinemist egiptuse usundist, viidates koptikeelsetes gnostilistes ürikutes leiduvate müstiliste sümbolite sarnasusele teatud egiptuse hieroglüüfidega, kuid tema argumendid ei ole leidnud teadlaste hulgas toetust. Reitzenstein, kes kirjutas monograafia hermetismist $^{70}$, nägi "Corpus Hermeticumis" tugevaid egiptuse usundi mõjusid ja püüdis tuletada hermeetilisi õpetusi egiptuse usundist. Ka gnoosises, mis on hermetismi "lähisugulane" arvates kujunesid egiptuse usundi mõju all gnostilised õpetused emanatsioonist, pleromast ja aioonipaaridest, mille moodustavad meessoost ja naissoost jumalused. $^{72}$ Bleeker oletab, et "Corpus Hermeticumis" esineva jumaliku naisolendi Ennoia taga peitub egiptuse jumalus Sia ja et roll, mida "Poimandreses" mängivad Nous ja Logos, vastab hästi "südame" ja "keele" rollile Ptahi teoloogias. ${ }^{73}$

Sarnasus egiptuse teogooniate ja gnostiliste teogooniate vahel on vaieldamatult olemas. Nii tekkis näiteks Hermopolise teogoonia järgi jumalik kaheksaainsus (ogdoaad), mille eesotsas seisab esimese jumalapaarina jumal Amon oma naispoole Amaunetiga. Ka gnostikutel kohtab jumalikku ogdoaadi, mille eesotsas on kõrgem jumalus oma naispoolega ja mis moodustab pleroma (Basilidesel) või seisab selle eesotsas (Valentinosel). Tähelepanuväärne on seegi, et me kohtame seda ogdoaadi Egiptuses tegutsenud gnostikute juures. Nii nagu Ištari müüdi puhul ei ole kindel, kas see on gnoosist otseselt mõjutanud või kujutab see gnostilisele lunastusmüüdile üksnes fenomenoloogilist paralleeli, nii jääb lahtiseks ka küsimus, kas Basilides ja Valentinos võtsid ogdoaadi üle egiptuse usundist või jõudsid nad selleni iseseisva spekulatsiooni tulemusena. "Corpus Hermeticumi" suhe egiptuse usundiga on väga problemaatiline $\mathrm{e}^{74} \mathrm{ja}$ otsestest egiptuse usundi mõjudest gnoosisele saab (ja ka üksnes oletamisi) rääkida vaid eshatoloogia osas. Nii egiptuse usundis kui gnoosises esineb allilma jaotus 12 osaks ja gnostilise kujutlusvõime loodud hirmuäratavad taevased tegelased on teisikuteks egiptuse surnuteraamatu omadele. ${ }^{75}$ Seepärast oletab Doresse, et egiptuse usund võis mõjutada gnostikute kujutlusi taevast ja allilmast. ${ }^{76}$

70 Reitzenstein, R. Poimandres. Leipzig, 1904.

71 M. P. Nilssoni määratluse järgi on hermetism koguni üks gnoosise haru (Nilsson, M. P. Geschichte der griechischen Religion. (Handbuch der Altertumswissenschaft, 5, 2.) Bd. 2. Die hellenistische und römische Zeit. Vierte, unveränderte Auflage. München, C. H. Beck, 1988, 611.

72 Puech, H. Ch. Das Problem des Gnostizismus, 336.

73 Bleeker, C. J. Muinas-Egiptuse usund. - Rmt: Widengren, G. \& Bleeker, C. J. (toim). Historia religionum, I, 94. Memphise teokosmogoonilises süsteemis loob jumal Ptah universumi oma "südame" (vaimu) ja "keele" (sõna) abil (Erman, A. Die ägyptische Religion. (Handbücher der königlichen Museen zu Berlin.) Zweite umgearbeitete Auflage. Berlin, Georg Reimer, 1909, 46).

74 Vt Lahe, J. Egiptuse kultused kreeka-rooma maailmas. - Tuna, 2004, 3, 22.

75 Bleeker, C. J. Muinas-Egiptuse usund, 94.

76 Doresse, J. Gnostitsism, 344. 
Rääkides egiptuse usundi võimalikest mõjudest gnoosisele, ütleb C. J. Bleeker, et Egiptuse kujunemine oluliseks gnoosise keskuseks ei ole juhuslik. Ta arvab, et kuna Egiptuses oli kõige kõrgemalt hinnatud omaduseks tarkus, elu ja surma mõistatuse taipamine, siis soodustas egiptuse vaimulaad ilmselt gnoosist. ${ }^{77}$ Julgen Bleekeriga polemiseerida ja öelda, et tema väide peab paika vaid osaliselt. Egiptuse usundis on pööratud tõesti erakordselt palju tähelepanu kosmogooniale ja sealpoolsuse problemaatikale (mis on kesksed ka gnoosises), ent muinasegiptuse usund erineb gnoosisest kardinaalselt ka selles osas: 1) mitte ükski muinasegiptuse kosmogooniline süsteem ei vaatle maailma tekkimist jumaliku olendi languse tagajärjena; 2) materiaalset maailma ei hinnata muinasegiptuse usundis halvana ${ }^{78}$; 3) sealpoolsus ei erine muinasegiptuse usundis kvalitatiivselt siinpoolsusest, vaid on viimase pikenduseks. Seega erineb muinasegiptuse usund gnoosisest juba oma põhikontseptsioonide poolest. Ka ei saa gnostilisi põhiõpetusi tuletada muinasegiptuse usundist. Järelikult ei ole alust arvata, et gnoosis on tekkinud muinasegiptuse pinnasest. ${ }^{79}$ Tänapäeval ei ole enam ka uurijaid, kes seda väidaksid.

\section{Iraani usund}

Kolmas muinasida usund, millest on otsitud gnoosise juuri, on muinaspärsia usund. Kuigi Uku Masing väidab, et ükski gnoosise vastu kirjutanud antiikautor ei ole vihjanud gnoosise iraani päritolule ${ }^{80}$, on ometi teada, et paljud gnostikud otsisid oma esivanemaid Iraanist. Nii pidas Mani end prohvet Zarathustra järglaseks. Plotinose õpilased Porphyrios ja Amelius mainivad, et nad kohtasid Roomas gnostikuid Adelphiust ja Aquiliniust, kes olid rajanud oma uskumused Zoroastri ${ }^{81}$ ja Zoroastriani (Zarathustra müütiline õpetaja) õpetustele. ${ }^{82}$ Nag Hammadist on leitud ka üks Zostrianosele omistatud apokalüps (NHC, VIII, 1). Uusajal on otsinud gnoosise päritolu Iraanist Reitzenstein, kelle hüpoteesile "lunastatud Lunastaja müsteeriumist" sai juba eelpool viidatud. Siinkohal olgu öeldud veel vaid nii palju, et Reitzensteini poolt formuleeritud "lunastatud Lunastaja" idee võib teoreetiliselt ilma eriliste raskusteta tuletada manihheistlikust materjalist, ent tuleb silmas pidada, et see on sõnastatud tekstidest ja müütidest lähtudes ja on manihheismi praktilises teoloogias vaevalt mingit rolli mänginud. ${ }^{83}$ Arvestades seda ja asjaolu, et "lunastatud Lunastaja" idee puudub enamikus gnostilistest süsteemidest,

77 Bleeker, C. J. Muinas-Egiptuse usund, 94.

78 P. Pokorny ütleb, et põhierinevuseks muinasegiptuse usundi ja gnoosise vahel on tõik, et egiptuse usund on kõikides oma avaldumisvormides optimistlik ja loomulikule elule lähedane, sellal kui gnoosis kuulutab maailmast põgenemist. Seepärast ei saa Pokorny arvates egiptuse usundi mõjuga gnoosisele arvestada (Pokorny, P. Der Ursprung der Gnosis. - Rmt: Rudolph, K. (Hrsg.). Gnosis und Gnostizismus, 756.

Lahe, J. Gnoosis ja algkristlus, 94.

80 Masing, U. Usklik Toomas. Eesti Evangeelne Luterlik Kirik 1984. Tallinn, EELK Konsistoorium, 1984, 22.

81 Zoroaster on Zarathustra kreekapärane nimekuju.

82 Doresse, J. Gnostitsism, 323.

83 Asmussen, J. P. Manihheism, 369. 
on Quispelil õigus väita, et "mingisugust lunastatud Lunastaja iraani müsteeriumi pole olemas olnud". ${ }^{84}$ Tänapäeval ei ole ideel "lunastatud Lunastajast" enam poolehoidjaid, kuid on teadlasi, kes pooldavad ikka veel hüpoteesi gnoosise Iraani päritolust. Neist tuntuim on G. Widengren, kelle arvates on kõik gnoosise põhiideed tuletatavad indoiraani mütoloogiast. ${ }^{85}$ Selliste ideedena nimetab Widengren gnoosise dualismi, Lunastaja kuju, kes on samal ajal ürginimene ja kes ilmutab end kui Salvator Salvatus, ja hinge taevareisi. ${ }^{86}$ H. J. W. Drijvers väidab aga Widengreni vastu, et gnoosise peateemad (nii nagu Widengren need esitab) ei ole ainult iraanlikud: teistsugusel kujul kohtame neid ka juutluses ja orfismis. ${ }^{87}$ Drijvers kritiseerib ka Widengreni pelgalt fenomenoloogilist lähenemist - fenomenoloogiline sarnasus eelnimetatud iraani usundi ideede ja gnostiliste kujutluste vahel ei tähenda veel ilmtingimata, et esimesed oleksid teisi ajalooliselt mõjutanud. Drijversi meelest on Widengreni meetodi suurim puudus see, et ta lahutab teineteisest võrdleva/fenomenoloogilise ning ajaloolise tööviisi ja kannab siis fenomenoloogilise võrdluse teel saadud tulemused üle ajaloolisse konteksti. Oma seisukoha põhjendamisel tugineb Widengren peamiselt "Pärlilaulule", kuid selle iraani päritolu pole üldse kindel. ${ }^{88}$

Kokkuvõtteks tuleb öelda, et gnoosise päritolu ei ole tuletatav Iraanist, kuid vaieldamatult leidub gnoosises iraani usundi elemente. Kõigepealt tuleks nimetada iraani usundi dualismi, milles on nähtud gnostilise dualismi mõjutajat. Jonas ${ }^{89}$, Rudolph $^{90}$ ja Drijvers ${ }^{91}$ rõhutavad küll iraani dualismi ja gnostilise dualismi põhimõttelist erinevust: iraani dualism ei ole ontoloogiline, vaid on eetiline dualism. Kuid sellele vaatamata ei välista nad iraani dualismi otsest mõju gnostilisele dualismile. Nii arvab Jonas, et gnoosis võis laenata dualismi skeemi Iraanist. ${ }^{92}$ Rudolph räägib iraani eetilise dualismi muutumisest ontoloogiliseks dualismiks, dualismiks halva kehalise maailma ja hea vaimumaailma vahel, millele antropoloogilisel pinnal vastab dualism keha ja hinge vahel. ${ }^{93}$ Kuid lisaks sellele võib rääkida gnoosises ka suurest hulgast konkreetsetest iraani usundi laenudest. Eriti rohkesti leidub neid manihheismis, mis on seletatav selle gnostilise usundi kujunemisega sassaniidide riigis, kus zoroastrism oli riigiusundiks. Iraani usundist pärineb manihheistlik kontseptsioon valguse ja pimeduse jumalast, kummagi jumala riigist (st valguse- ja pimeduseriigist) ning nende omavahelisest võitlusest, kujutlus valguse võidust pimeduse üle, viimsest kohtupäevast ja maailma hukkumisest ning õndsate igavesest elust paradiisis. Tõsi, enamik neist kujutlustest on olemas ka juutluses ja kristluses ${ }^{94}$,

${ }^{84}$ Quispel, G. Gnosis, 416.

85 Widengren, G. Religioonifenomenoloogia (käsikiri), II, 289-309; Widengren, G. Der iranische Hintergrund der Gnosis. - Rmt: Rudolph, K. (Hrsg.). Gnosis und Gnostizismus, 410 jj.

Drijvers, H. J. W. Die Ursprünge des Gnostizismus als religionsgeschichtliches Problem, 817.

Samas, 820.

Samas, 819-820.

Jonas, H. Gnosis und spätantiker Geist. Teil 1, 41 jj.

Rudolph, K. Die Gnosis, 68.

Drijvers, H. J. W. Die Ursprünge des Gnostizismus als religionsgeschichtliches Problem, 818-819.

Jonas, H. Gnosis und spätantiker Geist. Teil 1, 42.

Rudolph, K. Stand und Aufgaben in der Erforschung des Gnostizismus, 537-538.

Bois, M. Zoroastritsõ. Verovanija i obõtshai. Moskva, Evrarija, 1987, 136. 
ent nende iraani algupära on vaieldamatu. ${ }^{95}$ Ka paljud manihheismi jumalikud ja deemonlikud olendid pärinevad Iraanist või neil on vähemalt iraani nimed. Sellisteks olenditeks on näiteks pimeduseprints Ahriman (= Angra Mainyu, kes on ka zoroastrismis peamine kurjuse kehastus), Ohrmizd (= Ahura Mazda, kes on aga maniluses degradeeritud peajumalast esimeseks inimeseks, kes langeb pimedusejõudude ohvriks), Mihr (= jumal Mithra), kes on partia ja sogdi manihheistlikus traditsioonis Valguse Isa kolmas saadik ${ }^{96}$ jpt. Iraani usundist pärinevad maniluses ka kujutlus taevasest sillast, mida mööda lähevad hinged sealpoolsusesse ${ }^{97}$, ja kujutlus inimese taevasest teisikust, kellega ta pärast surma kohtub. ${ }^{98}$ Kontseptsioon pimeduse- ja valguseriigist ning nende omavahelisest võitlusest on aluseks ka mandalaste usundile, ja nagu maniluses nii on ka seal iraani usundi mõjud kõige tugevamad eshatoloogias. ${ }^{99} \mathrm{~K}$. Kasemaa arvab, et üks osa iraani usundist pärit kujutlustest on imbunud mandalaste usundisse Lähis-Ida üldisest sünkretistlikust miljööst ${ }^{100}$, milles iraani elemendil oli oluline koht ${ }^{101}$, teine osa neist on jõudnud sinna juutluse vahenduse ${ }^{102}$, kolmas osa on laenatud iraani usundist aga

95 Kõige rohkem ongi iraani usund mõjutanud teiste lähisida usundite eshatoloogiat. Vt Lahe, J. Iraani usundi eshatoloogia ja apokalüptika ning nende mõju teistele Lähis-Ida usunditele (käsikiri).

96 Asmussen, J. P. Manihheism, 383.

97 Selle prototüübiks on Cinvati sild iraani mütoloogias. Õigete jaoks on see sild üheksa oda laiune, patuste jaoks muutub see aga kitsaks kui "habemenoa tera" (Dinkart, IX, 20, 3). Silla all asub põrgusuu (Videvdat, 3, 7).

98 Selle prototüübiks on daena iraani usundis. Daena on inimese vaimne teisik, kes viibib taevases maailmas ja moodustab koos inimese hingega inimindiviidi "mina". Pärast surma ilmub ta inimesele sealpoolsuses naise kujul. Vastavalt sellele, kas inimese maised teod on olnud head või halvad, on tema daena ilus või inetu (Widengren, G. Die Religionen Irans. (Die Religionen der Menscheit, 14.) Stuttgart, W. Kohlhammer, 1965, 38).

99 Kasemaa, K. De origine et theologia mandaeorum, 44-45. Ka manda usundi eshatoloogias leidub kujutlus inimese taevasest teisikust, kellega hing peale surma ühineb (Op. cit., 44). Iraani usundist on mõjutatud kujutlus hinge tõusmisest taevasesse valgusemaailma, ja koguni sellistel eshatoloogilistel detailidel, nagu kujutlus taevasest varakambrist, kuhu hing tagasi pöördub, rõiva ja krooni üleandmine hingele ja tema istumine taevasele troonile, on olemas täpsed vasted iraani usundi eshatoloogias (Widengren, G. Die Religionen Irans, 298).

100 Kasemaa, K. De origine et theologia mandaeorum, 47.

101 Iraani usund ja kultuur on avaldanud Lähis-Idale mõju juba alates Ahhemeniidide valitsusajast (Widengren, G. Die Religionen Irans, 365). Aleksander Suure vallutuste tulemusena lülitati Iraan hellenistliku maailma koosseisu. Tekkis sünkretistlik kultuur, milles kreeka filosoofia ja kaldea astroloogia kõrval oli tähtis koht ka iraani usundist pärit kujutlustel (Russell, D. S. From Early Judaism to Early Church. Philadelphia, Fortress Press, 1986, 7). Nõnda hakkas iraani kultuur mõjutama kõiki hellenistlikku kultuuripiirkonda kuuluvaid rahvaid.

102 Kasemaa, K. De origine et theologia mandaeorum, 47. Iraani mõjud on täheldatavad SüüriaPalestiina alal juba sajandeid enne Kristuse sündi, seda nii kirjanduses, keeles, kunstis kui religioonis (Rudolph, K. Die Gnosis, 302). Iraani usundi mõjusid võib täheldada hellenismiajastu juutluse astroloogilistes ja kosmoloogilistes kirjutistes, angeloloogias ja demonoloogias (Russell, D. S. From Early Judaism to Early Church, 7). Kõige tugevamat mõju on avaldanud iraani usund aga juudi apokalüptikale; vt Gunkel, H. Zum religionsgeschichtlichen Verständnis des Neuen Testaments. Göttingen, Vandenhoek \& Ruprecht, 1903, 31 jj; Bousset, W. Die Religion des Judentums im späthellenistischen Zeitalter. In dritter verbesserter Auflage. (Handbuch zum Neuen Testament, 21.) Göttingen, Vandenhoeck \& Ruprecht, 1966, 515; Schreiner, J. Die apokalyptische Bewegung. - Rmt: Maier, J., Schreiner, J. (Hrsg.). Literatur und Religion des Frühjudentums. Eine Einführung. Würzburg, Gütersloher Verlagshaus. Gerd Mohn, 1973, 227; Hengel, M. Judentum und Hellenismus, 357, 358-359; Fohrer, G. Iisraeli usundi ajalugu. Tartu, Greif, 1997, 241; Russell, D. S. From Early Judaism to Early Church, 5. 
otse. ${ }^{103}$ Arvestades seda, et mandalased elasid sajandeid Pärsia valitsuse all, on viimane igati mõistetav. ${ }^{104}$ Iraani usundi panus gnoosise kujunemisse on üldtunnustatud ja seda aktsepteerivad ka need teadlased, kes ei tuleta gnoosist iraani usundist. ${ }^{105}$ Rudolph oletab, et suur osa iraani usundi ideedest pole jõudnud gnoosisesse mitte üldise sünkretistliku miljöö vahendusel ega laenatud otse iraani usundist, vaid et nende vahendajaks on olnud juutlus. ${ }^{106}$ Vahetuid iraani mõjusid näeb Rudolph peaasjalikult mandalaste usundis ja manihheismis. ${ }^{107}$

\section{TEOORIAD, MIS TULETAVAD GNOOSISE PÄRITOLU JUUTLUSEST}

Juba Justinus Märter, Irenäus ja Hippolytus väitsid, et gnoosise rajajaks on samaarlane Siimon Nõid ja järelikult pärineb ka gnostiline liikumine Samaariast. Ka Hegesippus püüdis tuletada kristlikku hereesiat mitmesugustest juudi sektidest (esseenid, galilealased, hemerobaptistid, masbotealased). ${ }^{108}$ Osa neist sektidest kuulub ristijate sektide hulka, teine osa juudikristlike sektide hulka, mis tegutsesid Tranjordaanias ja Mesopotaamia madalmikul. ${ }^{109}$ Siimon Nõia kuju on ümbritsetud legendide hämarusega ${ }^{110}$ ja paljud tänapäeva uurijad on juhtinud tähelepanu tõsiasjale, et gnostikuks on ta muutunud kiriklikus pärimuses alles aja jooksul. ${ }^{111}$ Seepärast on tänapäeva gnoosiseuurimine loobunud arvamusest, et Siimon on gnostilise religiooni rajaja. ${ }^{112}$ Kuid ta on kuni tänaseni esimene isik, kelle nimi seoses gnoosisega nähtavale ilmub. ${ }^{113}$ Kindel on seegi, et ta oli tuntud juba I sajandil ${ }^{114}$

\footnotetext{
103 Kasemaa, K. De origine et theologia mandaeorum, 47.

104 Samas, 47.

105 Näiteks Rudolph (Rudolph, K. Die Gnosis, 302-304).

106 Rudolph, K. Stand und Aufgaben in der Erforschung des Gnostizismus, 536; Rudolph, K. Die Gnosis, 302-303.

107 Rudolph, K. Die Gnosis, ibid.

108 Eusebios. Hist. eccl., IV, 22, 7.

109 Puech, H. Ch. Das Problem des Gnostizismus, 311.

110 Rudolph, K. Simon - Magus oder Gnosticus? Zum Stand der Debatte. - Theologische Rundschau, 42. Jahrgang. Tübingen, J. C. B. Mohr (Paul Siebeck), 1977, 279-359; vt ka Lüdemann, G. Untersuchungen zur simonianischen Gnosis. (Göttinger theologischen Arbeiten, 1.) Göttingen, Vandenhoeck \& Ruprecht, 1975.

111 Schmithals, W. Neues Testament und Gnosis. (Erträge der Forschung, 208.) Darmstadt, Wissenschaftliche Buchgesellschaft, 1984, 127; Beischlag, K. Simon Magus und die christliche Gnosis. (Wissenschaftlichen Untersuchungen zum Neuen Testament, 16.) Tübingen, J. C. B. Mohr (Paul Siebeck), 1974; Theißen, G. Die Religion der ersten Christen. Eine Theorie des Urchristentums. Gütersloh, Chr. Kaiser Gütersloher Verlagshaus, 2000, 317 jj.

112 Rudolph, K. Die Gnosis, 315. On ilmne, et gnoosise näol ei ole tegemist rajatud religiooniga, st usundiga, mille rajajaks on keegi konkreetne ajalooline isik. Selles osas võib gnoosise liigitada ühte kategooriasse muistsete lähisida usundite, müsteeriumiusundite ja hinduismiga, mitte aga budismi, kristluse või islamiga, mis on rajatud usundid.

113 Rudolph, K. Die Gnosis, 315.

114 Vanim allikas, kus teda mainitakse, on Apostlite tegude raamat, mille kirjutamine dateeritakse I sajandi lõpuga (Lohse, E. Uue Testamendi tekkelugu. Tartu, Eesti Üliõpilaste Seltsi Kirjastus, 1994, 136).
} 
ja et sekt, mille liikmed pidasid teda oma rajajaks (simoniaanid), tegutses Samaarias veel II sajandil. ${ }^{115}$ Hilisemal ajal on Samaarias tegutsenud ka gnostiline dositheaanide sekt. ${ }^{116}$ Uusaja teadlastest üritas esimesena gnoosise Samaaria päritolu tõestada Adolf Hilgenfeld ${ }^{117}$ ja ka mõned tänapäeva uurijad on püüdnud leida gnoosise juuri Samaariast. ${ }^{118}$

\section{Juudi-hellenistlik filosoofia}

Uusaja teaduses püstitas esmakordselt hüpoteesi gnoosise juudi päritolust Ferdinand Christian Baur, kes püüdis tuletada gnoosist juudi-hellenistlikust filosoofiast. ${ }^{119}$ Baur rõhutab oma töös eriti Aleksandria Philoni mõttemaailma lähedust gnoosisele. Philonit ei saa küll tänapäeval nimetada enam G. Karpelesi kombel "juudi-hellenistliku gnoosise esindajaks"120 ja ei saa nõustuda ka Doresse väitega, et põhiline osa kreeka filosoofilisest sõnavarast, mida gnostikud tarvitavad, tuleb koos Philoniga ${ }^{121}$, sest on ilmne, et Philoni kasutatud mõisted (logos, pnonoia, pneuma, hyle, kosmos, nous jne) pärinevad Philoni-eelsest filosoofiatraditsioonist. Küll on aga paljud neist mõistetest omandanud just Philoni filosoofias sarnase või ligilähedase tähenduse, nagu neil on gnoosises. ${ }^{122}$

115 Seda tõendab Justinus Märtri Apoloogia. Justinuse teatel olevat Siimon tegutsenud keiser Claudiuse valitsusajal (41-54 pKr) ja tema poolehoidjad olevat austanud teda kui "Esimest Jumalat", st Ürgjumalat (Apol., 1, 26, 1-3).

116 Bowman, J. Samaritanische Probleme. Studien zum Verhältnis von Samaritanertum, Judentum und Urchristentum. Franz Delitzsch-Vorlesungen, 1959. Stuttgart; Berlin; Köln; Mainz, W. Kohlhammer Verlag, 1967, $27 \mathrm{jj}$.

Hilgenfeld, A. Die Ketzergeschichte des Urchristentums. Leipzig, 1884.

118 Vt Caldwell, T. Dositheos Samaritanus. - Kairos, 1962, 4, 105-117; Kretschmar, G. Zur religionsgeschichtlichen Einordnung der Gnosis. - Evangelische Theologie, 1953, 13, 354361; Beltz, W. Samaritanertum und Gnosis. - Rmt: Tröger, K.-W. (Hrsg.). Gnosis und Neues Testament. Studien aus Religionswissenschaft und Theologie. Berlin, Evangelische Verlagsanstalt, 1973, 89-95; Perkins, P. Gnosticism and the New Testament. Minneapolis, Fortress Press, 1993, 20 jj; Fossum, J. E. The Name of God and the Angel of the Lord. Samaritan and Jewish Concepts of Intermediation and the Origin of Gnosticism. (Wissenschaftliche Untersuchungen zum Neuen Testament.) Tübingen, J. C. B. Mohr (Paul Siebeck), 1985; Tröger, K.-W. SpekulativEsoterische Ansätze (Frühjudentum und Gnosis). - Rmt: Maier, J., Schreiner, J. (Hrsg.). Literatur und Religion des Frühjudentums. Eine Einführung. Würzburg, Gütersloher Verlagshaus. Gerd Mohn, 1973, 317.

119 Baur, F. Ch. Die christliche Gnosis oder die christliche Religions-Philosophie in ihrer geschichtlichen Entwicklung. Tübingen, 1835.

120 Karpeles, G. Geschichte der jüdischen Literatur. Bd. 1. Berlin, Verlag von M. Poppenhauer, 1920, 193.

121 Doresse, J. Gnostitsism, 327.

122 Lahe, J. Gnoosis ja algkristlus, 81. Seepärast on ka tänapäeval uurijaid, kes tõmbavad paralleele Aleksandria Philoni filosoofia ja gnoosise vahele (nii tõmbab nt P. Pokorny paralleele Philoni Sophia- ning Logose-õpetuse ja gnoosise vahele; Pokorny näeb paralleele Philoni filosoofia ja gnoosise vahel õpetuses kahest inimesest (maisest ja ideaalsest inimesest) ja allegoorilises kirjaseletuses; vt Pokorny, P. Der Ursprung der Gnosis, 761) või räägivad Philoni filosoofia teedrajavast mõjust gnoosisele (R. McLachlan Wilson, vt McLachlan Wilson, R. The Gnostic Problem. London, 1958, 172 jj). 


\section{Heterodoksne juutlus vararabiinlikul ajajärgul}

Alates XIX sajandi keskpaigast on judaistikauurijad püüdnud leida jälgi gnoosisest ka juutlikest allikatest. Esmakordselt üritas seda teha H. Grätz ${ }^{123}$, kuid tema raamatut ei teata kuigi palju. Tuntuks sai aga $\mathrm{M}$. Friedländer, kes seostas rabiinlikus traditsioonis esinevaid vihjeid "ketseritele" (minim) gnostikutega. ${ }^{124}$ Osa ketserite kohta väidab pärimus, et nad õpetasid kahe jumala olemasolu. Ilmselt on sellega mõeldud juudi õpetajaid, kes õpetasid, et Jumalal on "asetäitja" Jaoel, kelle nimes sisaldub Jumala nimi (Jao on lühivorm Jahvest). Ta istub Jumala trooni kõrval pingil ja seepärast on tema nimeks ka Metatron - "kaastroonija". Mõned ketserlikud õpetajad läksid koguni nii kaugele, et väitsid, et Jaoel on loonud maailma ja kõnelnud prohvetite kaudu. ${ }^{125}$ Tuntuim taolistest ketseritest on Eliša ben Abuja, kes kannab hüüdnime Aher ("teine") ja kellel on juudi pärimuses sama koht mis Siimon Nõial kristlikus pärimuses - ta on esiketser. Friedländeri seisukohta on palju kritiseeritud, eriti J. Maieri poolt, kelle arvates on kindel, et nimetus minim, mida kasutati kõigi religioossete dissidentide kohta, käib kristlaste, täpsemalt juudikristlaste kohta. Eliša ben Abujat ei pea Maier gnostikuks ${ }^{126}$, ja Friedländeri poolt Talmudist otsitud kirjakohad, mis räägivad "kahe jumala austamisest", ei pärine Maieri arvates I sajandist, vaid hilisemast ajast. ${ }^{127}$ Quispel $^{128}$ ja Rudolph ${ }^{129}$ seostavad Friedländeri poolt käsitletud juudi hereetikuid siiski gnoosisega.

\section{Mandalased}

XIX sajandi lõpul ja XX sajandi algul hoogustunud mandalaste uurimine ${ }^{130}$ (Brandt ${ }^{131}$, Gunkel ${ }^{132}$ ) tõstatas taas küsimuse mandalaste päritolust. Brandt eristas mandalaste usundis erineva päritoluga elemente ja nimetas nende hulgas ka juutlusest pärinevaid ideid. ${ }^{133}$ Kuigi juba Brandt oli maininud mandalaste usundis ka

123 Grätz, H. Gnostizismus und Judentum. Krotischin, 1846.

124

Friedländer, M. Der vorchristliche Gnostizismus. Leipzig, 1898.

Quispel, G. Gnosis, 420.

Maier, J. Geschichte der jüdischen Religion. Von der Zeit Alexander des Grossen bis zur Aufklärung mit einem Ausblick auf das 19./20. Jahrhundert. Berlin; New York, Walter de Gruyter, 206; Maier, J. Jüdische Faktoren bei der Entstehung der Gnosis? - Rmt: Tröger, K.-W. (Hrsg.). Altes Testament - Frühjudentum - Gnosis. Neue Studien zu "Gnosis und Bibel”. Gütersloh, Gütersloher Verlagshaus Gerd Mohn, 1980, 255.

Maier, J. Jüdische Faktoren bei der Entstehung der Gnosis?, 252 jj.

Quispel, G. Gnosis, 420.

Rudolph, K. Stand und Aufgaben in der Erforschung des Gnostizismus, 588.

Lühiülevaate mandalaste uurimisest annab Rudolph, vt Rudolph, K. Die Mandäer, I. Prolegomena: Das Mandäerproblem. Göttingen, Vandenhoek \& Ruprecht, 1960, 13 jj.

Brandt, W. Die mandäische Religion. Leipzig, 1889.

Gunkel, H. Zum religionsgeschichtlichen Verständnis des Neuen Testaments, 18 jj.

Gunkel, H. Zum religionsgeschichtlichen Verständnis des Neuen Testaments, 18; Rudolph, K. Die Mandäer. Bd. I, 17. 
gnostiliste ideede olemasolu ${ }^{134}$, oli esimene teadlane, kes hakkas mandalaste usundit vaatlema gnostilise religioonina, Bousset. ${ }^{135}$ Käsitlus mandalaste religioonist kui ühest gnoosise vormist lõi aga laiemalt läbi alles tänu Hans Jonasele. ${ }^{136}$ Tänini on mandalaste päritolu küsimuses kaks konkureerivat hüpoteesi. Ühe hüpoteesi järgi on mandalaste kogukond tekkinud Palestiinas ja rännanud alles hiljem Mesopotaamiasse (Bultmann, Lidzbarski, Reitzenstein, Bousset, Kraeling, Odeberg, Schmid, Pedersen, Thomas, Nöldeke, Säve-Söderbergh, Baumgartner, Machuch, Segelberg, Schenke, Rudolph). Teise hüpoteesi järgi on mandalaste usund kasvanud välja babüloonia usundist (Brandt, Zimmern, Kessler, Rosenthal, Widengren) ja on seega autohtoonne mesopotaamia usund. Suurem osa teadlastest pooldab tänapäeval esimest hüpoteesi, sest mandalaste Palestiina päritolu kasuks kõneleb rida väga kaalukaid tõsiasju: läänearamea mõistete esinemine mandalaste idaarameamurdelises kirjanduses; paljude jumalike ja deemonlike olendite nimede juudi päritolu; "Jordani" sage esinemine mandalaste kirjanduses ning selle seos ristimisriitusega, mis on kindlasti laenatud Palestiinas tegutsenud ristijate sektidelt; Jeruusalemma sage mainimine manda pärimustes jms. ${ }^{137}$ Iseäranis on mandalaste usundi sidet juutlusega näidanud Kurt Rudolph. ${ }^{138}$ Tema seisukoht, et mandalaste päritolu tuleb otsida juutluse hereetilistest ringidest, on uurijate hulgas laialt tunnustust leidnud. ${ }^{139}$ Rudolph dateerib mandalaste sekti I sajandiga $\mathrm{pKr}^{140}$ või koguni eelkristliku ajaga. ${ }^{141}$ Mandalaste usund ei ole mingi gnostiline algsüsteem, millest saaks tuletada kõiki teisi gnostilisi süsteeme. Aga kui Rudolphi dateering peab

134 Gunkel, H. Zum religionsgeschichtlichen Verständnis des Neuen Testaments, 18; Rudolph, K. Die Mandäer. Bd. I, 17.

135 Rudolph, K. Die Mandäer. Bd. I, 17-18.

136 Samas, 20. See on ka põhjus, miks näiteks Hans Leisegang oma gnoosiseraamatus veel mandalasi ei käsitle.

137 Kasemaa, K. De origine et theologia mandaeorum, 26-33; Vielhauer, Ph. Geschichte der urchristlichen Literatur. Berlin; New York, Walter de Gruyter, 1975, 446-447; Rudolph, K. Die Mandäer. Bd. I, $60 \mathrm{jj}$.

138 Rudolph, K. Die Mandäer. Bd. I, 80-101; Rudolph, K. Quellenprobleme zum Ursprung und Alter der Mandäer. - Rmt: Rudolph, K. Gnosis und spätantike Religionsgeschichte. Gesammelte Aufsätze von Kurt Rudolph. (Nag Hammadi and Manichaen Studies.) Leiden; New York; Köln, E. J. Brill, 1996, 148 jj.

139 Rudolph, K. Die Mandäer. Bd. I, 252-255; Rudolph, K. Die Religion der Mandäer. - Rmt: Schröder, Ch. M. (Hrsg.). Die Religionen Altsyriens, Altarabiens und der Mandäer. (Die Religionen der Menschheit, 10, 2.) Stuttgart; Berlin; Köln; Mainz, Verlag W. Kohlhammer, 1970, 448-449; Rudolph, K. Stand und Aufgaben in der Erforschung des Gnostizismus. - Rmt: Rudolph, K. Gnosis und spätantike Religionsgeschichte, 532 jj; Rudolph, K. Entwicklungsgeschichte der mandäischen Religion. - Rmt: Widengren, G. (Hrsg.). Der Mandäismus. Wege der Forschung. Bd. CLXVII. Darmstadt, Wissenschaftliche Buchgesellschaft, 1982, 71 jj; Rudolph, K. Die Gnosis, 390-391; Rudolph, K. Quellenprobleme zum Ursprung und Alter der Mandäer. - Rmt: Rudolph, K. Gnosis und spätantike Religionsgeschichte, 428 jj; Schenke, H.-M. Das Problem der Beziehung zwischen Judentum und Gnosis. Ist die Gnosis aus dem Judentum ableitbar? - Kairos, 1965, 4, 129-130; Haardt, R. Die Gnosis, 10.

140 Rudolph, K. Die Gnosis, 390.

141 Rudolph, K. Quellenprobleme zum Ursprung und Alter der Mandäer, 428 jj. 
paika, siis on mandalaste sekt "samaaria gnoosise" kõrval teine tõend selle kohta, et meie ajaarvamise algul eksisteerisid juba Süüria-Palestiina ruumis gnostilised rühmitused.

\section{Juudi aines gnostilises kirjanduses}

Pärast Nag Hammadi käsikirjade avastamist ja avaldamist on selgunud, et juudi päritoluga aines on selles kirjanduses tähtsal kohal. Me kohtame Nag Hammadi tekstides palju mõisteid, motiive, ideid, tegelasi ja ka terveid jutustusi, mis pärinevad Vanast Testamendist või apokrüüfsest juudi kirjandusest. Nag Hammadi kirjanduses leidub ka palju mütoloogilisi kujusid ja mütologeeme, millel on juutlik taust (nt demiurg, aioon Sophia, Jumala troonvanker, Jumal nimega Inimene, Jumala vaim inimeses, seitse arhonti) ${ }^{142}$, ja mõnede Nag Hammadi tekstide puhul on ilmne, et nende traditsioonilugu põhineb semiidi-aramea sõnadel ja sõnamängudel. ${ }^{143}$ Van Unnik ${ }^{144}$ ja Maier ${ }^{145}$ väidavad, et Nag Hammadi teostes kasutatakse Vana Testamendi tekste väga vähe, kuid selle väitega ei pea ilmtingimata nõustuma. Van Unnik väidab näiteks, et Nag Hammadi kirjanduses on kasutatud eeskätt vaid Geneesise alglugusid ${ }^{146}$, kuid see väide ei pea paika: kasutatud on ka Kuningate raamatut, prohveteid, psalme jm. ${ }^{147}$ Vana Testamendi ainese tagasihoidlik hulk Nag Hammadi tekstides (kui me sellestki rääkida saame) ei pea tähendama gnostikute puudulikku piiblitundmist, nagu väidab Maier ${ }^{148}$. Pigem võib siin Rudolphi kombel rääkida "Piibli selektiivsest kasutamisest": gnostikud kasutasid vaid selliseid piiblitekste, mis olid kohandatavad gnostilistele põhikontseptsioonidele $^{149}$, st mida oli hea gnostiliselt (ümber)interpreteerida.

142 Schenke, H.-M. Das Problem der Beziehung zwischen Judentum und Gnosis, 124 jj; Rudolph, K. Die antike Gnosis - Probleme und Fakten. - Rmt: Franz, A. (Hrsg.). Gnosis oder die Frage nach Herkunft und Ziel des Menschen. Badeborn; München; Wien; Zürich, Verlag Ferdinand Schöningh GmbH, 2002, 13-39; Böhlig, A. Der jüdische und judenchristliche Hintergrund in gnostischen Texten von Nag Hammadi. - Rmt: Bianchi, U. (toim). Le origini dello gnosticismo, 109 jj; Quispel, G. Gnosis, 413 jj.

143 Rudolph, K. Die antike Gnosis - Probleme und Fakten, 31; Böhlig, A. Der jüdische und judenchristliche Hintergrund in gnostischen Texten von Nag Hammadi, 109 jj; Böhlig, A. Das Problem aramäischer Elemente in den Texten von Nag Hammadi. - Rmt: Böhlig, A. Gnosis und Synkretismus. Gesammelte Aufsätze zur spätantiken Religionsgeschichte von Alexander Böhlig. Tübingen, J. C. B. Mohr (Paul Siebeck), 1989, 414-453; Böhlig, A., Markschies, Chr. Gnosis und Manichäismus, 158-163.

an Unnik, W. C. Die jüdische Komponente in der Entstehung der Gnosis, 490

Maier, J. Jüdische Faktoren bei der Entstehung der Gnosis?, 242.

Van Unnik, W. C. Die jüdische Komponente in der Entstehung der Gnosis, 490.

Tröger, K.-W. Gnosis und Judentum. - Rmt: Tröger, K.-W. (Hrsg.). Altes Testament Frühjudentum - Gnosis, 165. Täpsemalt vt Rudolph, K. Bibel und Gnosis. Zum verständnis jüdisch-biblischer Texte in der gnostischen Literatur, vornehmlich aus Nag Hammadi. - Rmt: Rudolph, K. Gnosis und spätantike Religionsgeschichte, 198; Nagel, P. Die Auslegung der Paradieserzählung in der Gnosis. - Rmt: Tröger, K.-W. (Hrsg.). Altes Testament - Frühjudentum - Gnosis, $49 \mathrm{jj}$.

Maier, J. Jüdische Faktoren bei der Entstehung der Gnosis?, 242.

Rudolph, K. Bibel und Gnosis, 198. 
Nag Hammadist on leitud ka tekste, mis on mittekristlikku päritolu ${ }^{150}$ või on alles hiljem kristlikeks muudetud. ${ }^{151}$ Üks osa nendest teostest esindab juudi gnoosist. $^{152}$ Nagu juba viidatud, on juutluse mõjud tugevad ka mandalaste kirjanduses ${ }^{153}$, kuid isegi "paganlikus" "Corpus Hermeticumis" võib leida Vana Testamendi mõjusid. ${ }^{154}$ McLachlan Wilson juhib tähelepanu tõsiasjale, et silmatorkavalt palju gnoosisekeskusi asus piirkondades, kus juudi element oli rahvastiku hulgas tugev, näiteks Aleksandria ja Väike-Aasia. ${ }^{155}$ Kõikide nimetatud faktide põhjal väidavad paljud teadlased, et juutlus on gnoosise kujunemisel olnud olulisel kohal või peab gnoosise päritolu ülepea juutlusest tuletama, mida püüavad teha näiteks Stürmer, Kretschmar, Quispel, Pokorny, Danielou, McLachlan Wilson, Caldwell, Schubert, Nock, Peterson, McRae, Grant, Simon, Scholem, Perkins ja Iwersen. Schenke ja Rudolph ütlevad, et gnoosis kui originaalne negatiivne olemishoiak (negative Daseinshaltung) ja maailmavaade ei ole üldse tuletatav ei juutlusest ega kusagilt mujalt. ${ }^{156}$ Küll on aga konkreetsed elemendid, millest gnostilised süsteemid koosnevad, tuletatavad erinevatest Oriendi ja Kreeka religioossetest ning filosoofilistest pärimustest ${ }^{157}$ ja eriline koht kuulub siin Schenke, Trögeri ja Rudolphi järgi juudi pärimustele. ${ }^{158}$ Rudolphi arvates on gnoosise kujunemist mõjutanud eriti tuge-

150 Trögeri järgi on sellised tekstid Eugostose kiri, Aadama apokalüpsis, Bronte, Seti kolm sammast, Zostrianos, Norea, Marsanes ja Allogenes (Tröger, K.-W. Zum gegenwärtigen Stand der Gnosisund Nag-Hammadi-Forschung. - Rmt: Tröger, K.-W. (Hrsg.). Altes Testament - Frühjudentum - Gnosis, 21).

151 Trögeri järgi on sellised teosed Johannese apokrüüf, Egiptlaste evangeelium, Sophia Jesu Christi, kolmekujuline Protennoia (samas, 21).

152 Selliste teoste hulka kuuluvad Quispeli arvates nt Bronte ja Johannese apokrüüf (Quispel, G. Gnosis, 419, 422).

153 Rudolph, K. Die Mandäer. Bd. I, 80-101.

154 Rudolph, K. Stand und Aufgaben in der Erforschung des Gnostizismus, 526; Köster, H. Einführung in das Neue Testament im Rahmen der Religionsgeschichte und Kulturgeschichte der hellenistischen und römischen Zeit, 650; Van Unnik, W. C. Die jüdische Komponente in der Entstehung der Gnosis, 486; vt ka Nilsson, M. P. Geschichte der griechischen Religion. Bd. 2, 608 ja eriti Schenke, H.-M. Das Problem der Beziehung zwischen Judentum und Gnosis, 127-128.

155 McLachlan Wilson, R. Gnosis und Neues Testament, 29.

156 Schenke, H.-M. Das Problem der Beziehung zwischen Judentum und Gnosis, 126; Rudolph, K. Randerscheinungen des Judentums und das Problem der Entstehung des Gnostizismus. - Rmt: Rudolph, K. (Hrsg.) 774. Samas, 774.

Vt Schenke, H.-M. Das Problem der Beziehung zwischen Judentum und Gnosis, 124-133; Tröger, K.-W. Gnosis und Judentum. - Rmt: Tröger, K.-W. (Hrsg.). Altes Testament - Judentum - Gnosis, 155-168; Tröger, K.-W. Spekulativ-Esoterische Ansätze (Frühjudentum und Gnosis). - Rmt: Maier, J., Schreiner, J. (Hrsg.). Literatur und Religion des Früjudetums. Eine Einführung. Würzburg, Echter Verlag Würzburg. Gütersloher Verlagshaus. Gerd Mohn, 1973, 310-319; Tröger, K.-W. Die Gnosis. Heilslehre und Ketzerglaube. Freiburg; Basel; Wien; Herder, 2001, 72-73; Rudolph, K. Randerscheinungen des Judentums und das Problem der Entstehung des Gnostizismus. - Rmt: Rudolph, K. (Hrsg.). Gnosis und Gnostizismus, 768-797; Rudolph, K. Stand und Aufgaben in der Erforschung des Gnostizismus. - Rmt: Rudolph, K. (Hrsg.). Gnosis und Gnostizismus, 510-553; Rudolph, K. Die Gnosis, 297 jj. 
valt juudi tarkuseõpetus ja apokalüptika. ${ }^{159}$ Viimaste mõju gnoosise kujunemisele tunnistavad veel paljud teisedki teadlased. ${ }^{160} \mathrm{Ka}$ keskkonnaks, milles see uus "olemishoiak" hilisantiigis esmakordselt nähtavale ilmus, peavad Schenke ja Rudolph Süüria-Palestiina ruumi ${ }^{161}$, kus ristusid väga erinevate kultuuride ja usundite mõjud. Seda piirkonda peavad gnoosise tekkepaigaks ka Puech ${ }^{162}$, Köster ${ }^{163}$, Tröger $^{164}$ ja Böhlig $^{165}$. Pokorny ${ }^{166}$ ja Quispe ${ }^{167}$, kes näevad gnoosises tugevaid kreeka filosoofia mõjusid, peavad gnoosise tekkepaigaks aga hellenistlikku (eriti Egiptuse) juudi diasporaad. Quispel ütleb, et kuigi hellenistlikus juutluses ei ole võimalik tõestada ühegi tervikliku gnostilise süsteemi olemasolu, olid kõik nende tähtsamad koostisosad seal olemas juba eelkristlikul ajal ${ }^{168}$, ja ta püüab näidata, kuidas kõik gnoosise peamütologeemid saab sealt tuletada. ${ }^{169}$ Quispeli arvates on gnoosises kõige tähtsamaks mütologeemiks kujutlus jumalast, kelle nimi on Inimene (Anthropos). Ta peab kujutlust tollest jumalikust olendist terve gnoosise lähtepunktiks ja püüab näidata, kuidas saab seda kujutlust heterodokssest juutlusest geneetiliselt tuletada. ${ }^{170}$ Quispeli meetodit on palju kritiseeritud. Nii ütleb näiteks Kurt Schubert, et Quispel fundeerib oma teooriat vaid selliste rabiinlikust kirjandusest võetud tsitaatidega, mis tema teooriaga kokku sobivad, omistades neile nende algtähendusest erineva mõtte. Schuberti arvates pärinevad need tsitaadid alles II sajandist ja veelgi hilisemast ajast, nii et nende alusel ei saa rekonstrueerida eelkristlikku juudi gnoosist. ${ }^{171}$ Et aga kujutlusel anthropos 'est on juudi taust, on väljaspool kahtlust.

\section{Apokalüptika ja Qumran}

Kuna juba kirikuisad on väitnud, et esimesed gnostikud pärinesid Samaariast ja ka esimesed meile teadaolevad gnostilised sektid tekkisid Süüria-Palestiina

159 Rudolph, K. Die Gnosis, 297-301; Rudolph, K. Die antike Gnosis - Probleme und Fakten, 32.

Micha Brumlik (Brumlik, M. Die Gnostiker. Der Traum von der Selbsterlösung des Menschen, 25 jj), Josef Klauck (Klauck, H.-J. Die religiöse Umwelt des Urchristentums, II, 166) jt.

161 Schenke, H.-M. Hauptprobleme der Gnosis, 592; Rudolph, K. Randerscheinungen des Judentums und das Problem der Entstehung des Gnostizismus, 774-775.

162 Puech, H. Ch. Das Problem des Gnostizismus, 312.

163 Köster, H. Einführung in das Neue Testament im Rahmen der Religionsgeschichte und Kulturgeschichte der hellenistischen und römischen Zeit, 650.

164 Tröger, K.-W. Spekulativ-Esoterische Ansätze (Fühjudentum und Gnosis), 317.

165 Böhlig, A., Markschies, Ch. Gnosis und Manichäismus, 158 jj.

166 Pokorny, P. Die soziale Hintergrund der Gnosis. - Rmt: Tröger, K.-W. (Hrsg.). Gnosis und Neues Testament, 79; Pokorny, P. Der Ursprung der Gnosis, 761.

167 Quispel, G. Gnosis, 416.

168 Samas, 416.

169 Samas, 416-422.

170 Quispel, G. Der gnostische Anthropos und die jüdische Tradition. - Rmt: Quispel, G. (Hrsg.). Gnostic Studies, I. Istanbul, Nederlands Historisch-Archaelogisch Instituut in Het Nabije Oosten, 1974, 173-195; Quispel, G. Gnosis, 416-418.

171 Schubert, K. Problem und Wesen der jüdischen Gnosis. - Kairos, 1961, 2. 
ruumis, siis püüavad mõned teadlased tuletada gnoosise päritolu ka Palestiina juutlusest. ${ }^{172}$ Uurijaid, kes on tuletanud gnoosise päritolu Samaariast, sai juba nimetatud. R. M. Grant tuletab gnoosise tekkimise apokalüptikast, millele on juba iseenesest omased dualistlik maailmapilt ja pessimistlik eluhoiak (maailm läheb vastu hävingule), millele lisandub natsionalistliku messianismi kokkuvarisemine pärast Jeruusalemma hävitamist roomlaste poolt $(70 \mathrm{pKr})$. Sellega olevat seletatav gnoosise pessimistlik hoiak ja Jahve degradeerumine kurjaks demiurgiks (Granti arvates pettusid paljud juudid temas Jeruusalemma katastroofi tõttu) ${ }^{173}$ Granti radikaalne hüpotees ei ole omaksvõttu leidnud, kuid apokalüptika mõju gnoosise kujunemisele on väljaspool kahtlust. Gnoosise päritolu on püütud tuletada ka Qumrani teoloogiast. Juba R. Lipsius otsis gnoosise juuri esseenlusest, kuigi tema ja tema ajastu teadmised sellest liikumisest piirdusid vaid Josephus Flaviuse jt antiikautorite teadetega. ${ }^{174}$ Uurijatest, kes on kirjutanud gnoosise esseenlikust päritolust pärast Surnumere käsikirjade avastamist (1947), tuleb eriti nimetada Kurt Schubertit, kes leiab Qumrani teoloogiast kõik peamised gnostilised jooned (dualism, tunnetuse tähtsuse rõhutamine jne). ${ }^{175}$ Kuigi gnoosise ja Qumrani teoloogia vahelised paralleelid on ilmsed ${ }^{176}$ ja Rudolph on tõestanud, et mandalaste ja Qumrani sekti kujutluste vahel leidub kokkupuutepunkte ${ }^{177}$, väidetakse Qumrani teoloogia otsest mõju gnoosise kujunemisele siiski harva. ${ }^{178}$ Viimaks on püütud gnoosise päritolu tuletada ka juudi müstikast, eriti G. Scholem. ${ }^{179}$ Schubert nimetab kogu varasemat juudi müstikat "juudi gnoosiseks" (die jüdische Gnosis) ${ }^{180}$, kuid Rudolph ${ }^{181}$, Maier $^{182}$ ja Van Unnik ${ }^{183}$ on selle mõiste vastu, sest rangelt võttes puudub sellel

172 Seejuures ei tohi unustada, et Palestiina ja diasporaa vahel olid tihedad kontaktid ja et piir Palestiina juutluse ja diasporaajuutluse vahel oli väga voolav (Hengel, M. Judentum und Hellenismus. Tübingen, 1973; Rudolph, K. Die Gnosis, 304; Schenke, H.-M. Hauptprobleme der Gnosis, 133; Böhlig, A., Markschies, Ch. Gnosis und Manichäismus, 166; Iwersen, J. Gnosis zur Einführung. Hamburg, Junius Verlag GmbH, 2001, 21-22.

Grant, R. M. Gnosticism and Early Christianity. New York, Columbia University Press, 1959, 39-69.

Lipsius, R. Gnostizismus, sein Wesen, Ursprung und Entwicklungsgang. Leipzig, 1860.

Schubert, K. Problem und Wesen der jüdischen Gnosis, 5 jj; Schubert, K. Die Religion des nachbiblischen Judentums. Freiburg; Wien, Verlag Herder, 1955, 85-87; Schubert, K. Die Gemeinde vom Toten Meer. Ihre Entstehung und ihre Lehren. München; Basel, Ernst Reinhardt, $1958,66 \mathrm{jj}$.

176 Rudolph, K. Die Gnosis, 300.

177 Rudolph, K. Stand und Aufgaben in der Erforschung des Gnostizismus, 526.

178 Tröger, K.-W. Gnosis und Judentum, 155.

179 Scholem, G. Jewish Gnosticism, Merkabah Mysticism and Talmudic Tradition. New York, 1960; Scholem, G. Die jüdische Mystik in ihren Hauptströmungen. Zürich, 1957; Scholem, G. Zur Kabbala und ihrer Symbolik. Zürich, 1960.

180 Schubert, K. Problem und Wesen der jüdischen Gnosis, 2 jj.

181 Rudolph, K. Randerscheinungen des Judentums und das Problem der Entstehung des Gnostizismus, $782 \mathrm{jj}$.

182 Maier, J. Geschichte der jüdischen Religion, 193-194; Maier, J. Jüdische Faktoren bei der Entstehung der Gnosis? - Rmt: Tröger, K.-W. (Hrsg.). Altes Testament - Frühjudentum Gnosis, 239-258. 
müstikal gnostiline maailmapilt. Nad soovitavad selle asemel jääda mõistete "juudi esoteerika" või "juudi müstika" juurde. ${ }^{184}$ Scholem kasutab juudi esoteerika kohta mõistet "ortodoksne juudi gnoosis", vastandades seda "hereetilisele juudi gnoosisele". Quispel nimetab viimast "juudi heterodoksiaks" "185, Rudolph räägib "juutluse perifeerianähetest" (die Randerscheinungen des Judentums) ${ }^{186}$, ent Maier ${ }^{187}$, Van Unnik ${ }^{188}$ ja Drijvers ei pea taolist terminoloogiat õigustatuks: nende arvates ei saa veel enne Jeruusalemma katastroofi ja sellele järgnenud juutluse uut konsolideerumist rääkida juudi ortdodoksiast või "normatiivsest juutlusest". ${ }^{189}$ Me kohtame juudi müstikas mitmeid motiive, mis on olemas ka gnoosises - kujutlus Jumala troonist, mille juurde müstik peab tõusma läbi seitsme taevasfääri jms, kuid samas puuduvad varases juudi müstikas sellised gnoosisele tunnuslikud teemad, nagu vastuolu hea transtsendentse Jumala ja kurja, maailma loonud jumaluse vahel või kujutlus jumalikust valgusesädemest, mis tuleb maailmast lunastada. ${ }^{190}$ Seepärast ei pea R. Leichti arvates tuletama gnoosist juudi müstikast, vaid võib rääkida "paralleelarengute võimalusest" ja ühistest eellastest (apokalüptika). ${ }^{191}$

\section{Vastuargumendid teooriale gnoosise juudi päritolust}

Teooriale gnoosise juudi päritolust on esitatud ka palju vastuväiteid: 1) gnoosis ei ole juutlusest tuletatav, kuna gnoosise ja juutluse alusprintsiibid on teineteisega teravas vastuolus: juutluse range monoteism ja maailma (st loodut) jaatav hoiak on vastuolus gnostilise dualismi ja antikosmilise hoiakuga ${ }^{192}$; 2) juudi päritoluga aines on gnoosises põhjalikult ümber töödeldud ja omandanud mitte ainult uue, vaid kohati lausa vastupidise tähenduse, kui tal on juutluses: Looja-Jumalast

183

184

\section{Samas, 239-258.}

Rudolph, K. Randerscheinungen des Judentums und das Problem der Entstehung des Gnostizismus, 783; Maier, J. Geschichte der jüdischen Religion, 193-194; Van Unnik, W. C. Gnosis und Judentum, 75-76.

Quispel, G. Gnosis, 423.

E. Haenchen on kirjutanud ka sama pealkirjaga artikli, vt Haenchen, E. Gab es eine vorchristliche Gnosis? (Zeitschrift für Theologie und Kirche, 1952, 49, 316-349.)

Maier, J. Jüdische Faktoren bei der Entstehung der Gnosis?, 252.

Van Unnik, W. C. Gnosis und Judentum, 75-76.

Teisiti arvab Iwersen, kes paigutab juudi ortodoksia kujunemise vahetult Paabeli vangipõlvest tagasitulekule järgnenud aega (Iwersen, J. Gnosis zur Einführung, 15).

Schubert, K. Problem und Wesen der jüdischen Gnosis, 4.

Leicht, R. Gnosis/Gnostizismus, IV. Judentum. - Rmt: Religion in Geschichte und Gegenwart. Handwörterbuch für Theologie und Religionswissenschaft. Vierte, völlig neu bearbeitete Auflage. Tübingen, J. C. B. Mohr (Paul Siebeck), 2000, 1056-1057.

Adam, A. Ist die Gnosis in aramäischen Weisheitschulen Entstanden? - Rmt: Bianchi, U. (Hrsg.). Le Origini dello Gnosticismo, 300; Tröger, K.-W. Judentum und Gnosis, 160; Strecker, G. Judenchristentum und Gnosis. - Rmt: Tröger, K.-W. (Hgrs.). Altes Testament - Frühjudentum - Gnosis, 269; Haardt, R. Die Gnosis, 12; Schubert, K. Problem und Wesen der jüdischen Gnosis, 2; Böhlig, A., Markschies, Ch. Gnosis und Manichäismus, 168. 
on saanud kuri demiurg, pattulangusest positiivne õndsussündmus jne ${ }^{193}$; 3) gnostilises kirjanduses esineb tugev antijuutlik hoiak: Jahve on kuri jumalus, juutluse seitse peainglit on demoniseeritud, juute juhitakse kurjade kosmiliste jõudude poolt jne. ${ }^{194}$ On oletatud, et esimesed gnostikud pärinesid mingist väga radikaalselt sünkretistlikust juudi rühmitusest. ${ }^{195}$ Hellenismiajastu ja meie ajaarvamise alguse juutlus oli küll väga pluralistlik ja hõlmas ka rühmitusi, mis olid tugevalt võõrmõjudele avatud, kuid pole teada ühtki juudi rühmitust, mis oleks traditsioonilised juudi kujutlused Jumalast ja maailmast nii radikaalselt ja totaalselt pahupidi pööranud ja ümber hinnanud, kui seda tegid gnostikud. ${ }^{196}$ Seepärast väidavad näiteks Maier ${ }^{197}$ ja Drijvers ${ }^{198}$, et esimesed gnostikud ei saanud olla juudid, kuid nad pidid olema inimesed, kes tundsid juudi pärimusi. Van Unnik oletab, et nad võisid olla proselüüdid või jumalakartlikud, kes hiljem usust taganesid. ${ }^{199}$ Renegaatide hüpoteesi pooldavad ka Tröger ${ }^{200}$ ja Maier. ${ }^{201}$ Grant $^{202}$ ja Theißen $^{203}$ seletavad gnostilist antijudaismi ühe osa juutide läbielamistega Jeruusalemma katastroofis aastal $70 \mathrm{pKr}$ : selle katastroofi mõjul purunes osa juutide usk niivõrd, et nad minetasid oma senise usulise identiteedi ja hindasid oma usu radikaalselt ümber. Van Unnik ${ }^{204}$ ja Berger ${ }^{205}$ juhivad seevastu tähelepanu Jeruusalemma katastroofi kajastavatele juudi allikatele (IV Esra, Baaruki apokalüpsis) ja ütlevad, et see katastroof ei saanud selliste tagajärgedeni viia. Ühe võimaliku seletuse gnostikute antijuutliku hoiaku suhtes võiks pakkuda mandalaste kirjandus, milles on juttu mandalaste tagakiusamisest juutide poolt; üksikasjades ei ole see sündmus küll enam rekonstrueeritav ${ }^{206}$, aga see seletaks mandalaste antijudaismi: võib-olla pärinesid esimesed mandalased (ja gnostikud üldse) sellistest religioossetest gruppidest, kellele sai osaks tagakiusamine juutide poolt. ${ }^{207}$ Antijuutlik hoiak oli olemas, tõsi küll, ka varases kristluses, kuid mandalaste puhul seda risiusust tuletada ei saa, sest mandalased ei ole ristiusust mõjutatud. ${ }^{208}$ Survega juutluse poolt seletab

Drijvers, H. J. W. Die Ursprünge des Gnostizismus als religionsgeschichtliches Problem, 813.

Iwersen, J. Gnosis zur Einführung, 19.

Tröger, K.-W. Gnosis und Judentum, 166.

Samas, 166.

Maier, J. Jüdische Faktoren bei der Entstehung der Gnosis?, 249-250.

Drijvers, H. J. W. Die Ursprünge des Gnostizismus als religionsgeschichtliches Problem, 831.

Sellistest inimestest räägib näiteks Josephus Flavius (Contra Apionem, II, 10).

Tröger, K.-W. Gnosis und Judentum, 166.

Maier, J. Jüdische Faktoren bei der Entstehung der Gnosis?, 249-250.

Grant, R. M. Gnosticism and Early Christianity. New York, 1959.

Theißen, G. Die Religion der ersten Christen, 317.

Van Unnik, W. C. Die jüdische Komponente in der Entsehung der Gnosis, 484.

Berger, K. Gnosis/Gnostizismus, I. Vor- und außerchristlich. - Rmt: Theologische Realenzyklopädie. Bd. XIII. Berlin; New York, Walter de Gruyter, 1984, 532-533.

Iwersen, J. Gnosis zur Einführung, 20.

Samas, 20.

Õigupoolest tuleb öelda, et mandalaste usundis on mitmeid kristlikke elemente, kuid need on sekundaarsed ega võimalda kuidagi oletada manda usundiloos mingit kristlikku - kuigi hereetilist - staadiumi (Kasemaa, K. De origine et theologia mandaeorum, 33). 
mandalaste antijuutlikku hoiakut ka Kasemaa, kes peab võimalikuks, et mandalased võisidki Mesopotaamiasse rännata juutliku šovinismi survel; ta peab võimalikuks, et see võis toimuda seoses Bar Kochba ülestõusuga (132-135 pKr). ${ }^{209}$

\section{GNOOSISE PÄRITOLU "PLURALISTLIKUD” TULETAMISKATSED. GNOOSIS KUI ORIGINAALNE OLEMISHOIAK}

Gnoosise päritolu on püütud tuletada küll erinevatest usunditest, kuid tänapäeval valitseb seisukoht, et gnoosist ei ole võimalik tuletada ühest konkreetsest usundist. Õigupoolest kohtab seda vaateviisi juba ka paljudel varasematel uurijatel. Nii arvas näiteks Bousset, et gnoosis tekkis Mesopotaamias ja babüloonia usundi baasil, aga ta pidas gnoosise tekkimise jaoks määravaks ka zoroastrismi mõju. Rudolph usub, et gnoosise kujunemine toimus Süüria-Palestiina ruumis ja et gnostiline olemishoiak ilmus esmakordselt nähtavale teatud juutluse ringides, kuid juudi pärimuste kõrval arvestab ta tõsiselt ka iraani usundi ja kreeka filosoofia mõjudega. Quispel peab gnoosise tekkepaigaks hellenistlikku juudi diasporaad, kuid temagi peab juudi ainese kõrval gnoosise tekkimisel määravaks kreeka filosoofia mõju. Tänapäeval on väga vähe uurijaid, kes arvestavad gnoosise tekkimise juures eeskätt vaid ühe usundi mõjuga. Teisalt ollakse tänapäeval tagasihoidlikud ka märksõnaga "sünkretism" "210, sest on saanud selgeks, et kuigi gnoosises võib eristada erinevate usundite elemente, ei saa teda taandada vaid nende summaks. Kui veel A. von Harnack väitis, et gnoosis pole muud kui üksnes I ja II sajandi suure sünkretistliku liikumise üks avaldusvorm ${ }^{211}$, siis Leisegang nägi juba asja teisiti: ka tema jaoks on gnoosis "mosaiik" 212 , kuid tal on oma spetsiifiline vaimne struktuur, mis teda teistest usunditest ja filosoofiasüsteemidest eristab. Juudi, kristlikud, pärsia, babüloonia, egiptuse ja kreeka religioonielemendid on Leisegangi arvates vaid "ehitusmaterjal" (das Baumaterial) mosaiigi jaoks, mis ei ole aga tema sisemise vormi ja vaimse struktuuriga identne. Milline on gnoosise vaimne, sisemine struktuur, seda püüab Leisegang kirjeldada oma teedrajavas teoses "Die Gnosis", mille esmatrükk ilmus 1924. a. Samamoodi väitis Bultmann oma "Uue Testamendi teoloogias", mille esmatrükk ilmus 1948. aastal, et gnoosise olemus ei seisne tema sünkretistlikus mütoloogias, vaid "antiikse maailmaga võrreldes uues maailma- ja enesemõistmises". ${ }^{213}$ Sünkretistlik mütoloogia on Bultmanni meelest vaid väljendusvahend selle maailma- ja enesemõist-

209 Samas, 84.

210

Eriti on kutsunud üles sellesse mõistesse kriitiliselt suhtuma K. Rudolph. Vt Rudolph, K. Synkretismus: vom theologischen Scheltwort zum religionswissenschaftlichen Begriff. - Rmt: Rudolph, K. (Hrsg.). Geschichte und Probleme der Religionswissenschaft. Leiden, E. J. Brill, 1992, 193-215.

211 Harnack, A. v. Dogmengeschichte. Berlin, 1922, 64.

212 Leisegang, H. Die Gnosis, 5.

213 Bultmann, R. Theologie des Neuen Testaments. 9. Auflage, durchgesehen und ergänzt von Otto Merk. Tübingen, J. C. H. Mohr (Paul Siebeck), 1984, 168. 
mise jaoks. ${ }^{214}$ Bultmanni arusaama gnoosise olemusest võttis üle tema õpilane Hans Jonas, kes mõistis gnoosist kindla "olemishoiakuna (Daseinshaltung) ja sellest kantud algupärase olemistõlgendusena (Daseinsdeutung)". ${ }^{215}$ Jonase arvates saab üksikud gnostilised ideed tuletada küll antiiksetest religioonidest ja filosoofiasüsteemidest (Jonas arvestab siin eeskätt kahe religiooni ja ühe filosoofiasüsteemiga. Nendeks on zoroastrism, juutlus ja platonism). Nende ideede süntees on aga "täiesti uus gnoosises" (das ganz Neue in der Gnosis), mis ei lase ennast millegi muuga ära vahetada. See uus avaldub "antikosmilise olemishoiakuna" (antikosmische Daseinshaltung), st absoluutselt negatiivse hoiakuna materiaalse olemise suhtes. Jonase gnoosise olemuse mõistmine on leidnud teaduses suurt tunnustust ja selle on omaks võtnud näiteks Schenke ${ }^{216}$, Colpe $^{217}$, Tröger ${ }^{218}$, Böhlig $^{219}$, Köster $^{220}$ ja Rudolph. ${ }^{221}$ Rudolph ütleb aga, et selle uue olemishoiaku tuletamatus ühestki vanast religioonist ei tähenda üldsegi seda, et me ei peaks püüdma välja selgitada üksikute gnostiliste ideede religiooniloolist päritolu. ${ }^{222}$ Rudolph kuulub nende teadlaste hulka, kes on püüdnud geograafiliselt täpselt fikseerida ka piirkonda, kus see uus olemishoiak esmakordselt nähtavale ilmus (ta peab selleks Süüria-Palestiina ruumi), ja ta peab võimalikuks välja selgitada ka põhjusi, mis selle olemishoiaku tekkimisele viisid. ${ }^{223}$ Käesoleva artikli autor pooldab samuti alates Leisegangist alguse saanud käsitlust gnoosisest kui varasema antiigiga võrreldes uuest jumala-, maailma- ja inimesemõistmisest. Piirkonnaks, kus see uus olemiskäsitlus aga esmakordselt nähtavale ilmus, peab ta koos paljude eelnimetatud uurijatega juutide asuala, olles veendunud, et gnoosise kujunemise juures on mänginud väga suurt rolli juudi pärimused. Nimetatud teemat vaatleb ta põhjalikumalt oma magistritöös "Die Berührungspunkte zwischen Gnosis und Judentum und ihre Widerspiegelungen in den authenthischen Briefen des Paulus" (Tartu, 2004, käsikiri).

\section{GNOOSISE TEKKEAEG}

Lõpuks tuleb öelda veel paar sõna gnoosise tekkeaja küsimuse kohta. Võtmeprobleemiks on, kas on olnud eelkristlik gnoosis. Paljud teadlased, nagu näiteks Friedländer, Kessler, Anz, Bousset, Reitzenstein, Gunkel, Bultmann, Schmithals,

214

215

216

Colpe, C. Gnosis, I. Religionsgeschichtlich. - Rmt: Die Religion in Geschichte und Gegenwart.
Handwörterbuch für Theologie und Religionswissenschaft. Bd. 2. Tübingen, J. C. H. Mohr
(Paul Siebeck), 1958, 1649 .

Jonas, H. Gnosis und spätantiker Geist. Teil 1, 80.

Schenke, H.-M. Das Problem der Beziehung zwischen Judentum und Gnosis, 126.

Tröger, K.-W. Gnosis und Judentum, 161.

Böhlig, A., Markschies, Ch. Gnosis und Manichäismus, 167.

Köster, H. Einführung in das Neue Testament im Rahmen der Religionsgeschichte und Kulturgeschichte der hellenistischen und römischen Zeit, 395.

Rudolph, K. Randerscheinungen des Judentums und das Problem der Entstehung des Gnostizismus, 774.

Samas, 774.

Samas, 774 . 
Lohse $^{224}$, Adam ${ }^{225}$, Quispel ja Vielhauer, usuvad, et gnoosis oli olemas juba eelkristlikul ajal või peavad seda vähemalt tõenäoliseks. ${ }^{226}$ Teised, nagu näiteks von Harnack, Percy, Petrement, Colpe ja Berger, seevastu ei usu eelkristliku gnoosise olemasolu ja arvavad, et gnoosis on tekkinud hiljem kui ristiusk ja on kirikusisene fenomen. Kolmas rühm teadlasi, nagu näiteks Haenchen, Schenke ja Lohse, usuvad küll eelkristliku gnoosise olemasolu, aga mõtlevad viimase all tegelikult mittekristlikku gnoosist, mida esindavad näiteks mandalaste usund või hermeetiline traktaat "Poimandres". Õigesti on selle kohta öelnud Drijvers: "Mittekristlik ei tähenda veel ilma pikemata eelkristlik" ${ }^{227}$, st kui mõni gnostiline süsteem ei ole kristlik, siis ei tähenda see veel, et ta oleks tekkinud eelkristlikul ajal. Nii on sageli toodud Nag Hammadi mittekristlikke või alles hiljem kristlikeks muudetud tekste selle tõestuseks, et gnoosis oli olemas juba eelkristlikul ajal, kuid viimaste olemasolu seda siiski ei tõesta. Nimetatud kolmanda teadlaste rühma puhul võib aga rääkida lihtsalt ebaselgest terminoloogiast, sest nähtus, mida nad nimetavad "eelkristlikuks gnoosiseks", tekkis nende arvates ligikaudselt samal ajal kristlusega. ${ }^{228}$ Seejuures toonitavad Schenke ${ }^{229}$, Haardt ${ }^{230}$, McLachlan Wilson $^{231}$ ja Theißen ${ }^{232}$, et gnoosis on tekkinud ristiusust sõltumatult.

\section{Argumendid gnoosise eelkristliku päritolu kasuks}

Eelkristliku gnoosise tõenduseks on toodud erinevaid argumente. Reitzensteini jaoks oli põhiargumendiks see, et gnoosise aluseks olev müüt "lunastatud Lunastajast" oli olemas juba eelkristlikul ajal. Selle müüdi olemasolu eelkristlikul ajal ei kinnita aga miski ja küsitav on ka, kas seda müüti saab pidada gnoosise aluseks. Colpe on veenvalt näidanud, kuivõrd nõrgal alusel seisab kogu "lunastatud Lunastaja" problemaatika. Quispel toob gnoosise eelkristliku eksistentsi kinnituseks fakti, et enamik olulisi gnostilisi mütologeeme olid hellenistlikus diasporaajuutluses olemas juba eelkristlikul ajal. ${ }^{233}$

224 Lohse, E. Umwelt des Neuen Testaments. 7., durchgesehene Auflage. (Grundrisse zum Neuen Testament. Das Neue Testament Deutsch.) Göttingen, Vandenhoeck \& Ruprecht, 1986, 198.

225 Adami arvates on gnoosis tekkinud eelkristlikul ajal arameakeelsetes tarkusekoolides (Adam, $\mathbf{A}$. Ist die Gnosis in aramäischen Weisheitsschulen entstanden?, 291-301). Adami hüpoteesi pooldab ka Tröger (Tröger, K.-W. Die Gnosis, 15), kuid juudi tarkuseõpetust peavad üheks gnoosise mõjutajaks paljud gnoosiseuurijad (Rudolph, K. Die Gnosis, 300-301; Tröger, K.-W. Gnosis und Judentum, 160-161).

226 Conzelmann, H., Lindemann, A. Arbeitsbuch zum Neuen Testament. 13. Auflage. Tübingen, J. C. B. Mohr (Paul Siebeck), 2000, 214.

227 Drijvers, H. J. W. Die Ursprünge des Gnostizismus als religionsgeschichtliches Problem, 820.

228 Schenke ütleb: kas pisut enne kristluse tekkimist või samal ajal kui kristlus (Schenke, H.-M. Hauptprobleme der Gnosis, 592).

229 Schenke, H.-M. Hauptprobleme der Gnosis, 592.

230 Haardt, R. Die Gnosis, 9.

231 McLachlan Wilson, R. Gnosis/Gnostizismus, II. Neues Testament, Judentum, Alte Kirche. Rmt: Theologische Realenzyklopädie. Bd. XIII. Berlin; New York, Walter de Gruyter, 1984, 536.

232 Theißen, G. Die Religion der ersten Christen, 320-321.

233 Quispel, G. Gnosis, 416 jj. 


\section{Argumendid gnoosise eelkristliku päritolu vastu}

Mitme gnostilise mütologeemi olemasolu eelkristlikus hellenistlikus diasporaajuutluses on tõestatav. Sellised on näiteks kujutlus taevasest inimesest ja maailma loomisest ühe Jumalast madalama jumaliku jõu poolt (nagu logos Philonil). Kuid samas puuduvad eelkristlikus hellenistlikus diasporaajuutluses mõned gnostikutele väga olulised mütologeemid, nagu näiteks idee sellest, et sealpoolsest maailmast pärit vaim on inimesse vangistatud ja igatseb lunastust. Nagu juba öeldud, ei saa, lähtudes arusaamast, et gnoosis on eeskätt olemishoiak, taandada gnoosist ainult teda moodustavatele elementidele (st üksikutele kujutlustele või mütologeemidele) ja Quispel möönab ka ise, et ei ole võimalik tõestada juudiusu müsteeriumide või mõne tervikliku gnostilise süsteemi olemasolu hellenistlikus diasporaas. ${ }^{234}$ Gnoosise eelkristliku päritolu vastu on esitatud veel teisigi argumente. Põhilised neist võtab McLachlan Wilson kokku järgnevalt:

1) ükski meile tuntud gnostiline dokument ei pärine Uue Testamendi eelsest ajast;

2) mõned Nag Hammadi tekstid on küll kindlasti sekundaarselt kristianiseeritud, aga meil ei ole nende mittekristlikke versioone; mittekristlik ei tähenda ka iseenesest eelkristlikku;

3) me ei tunne ühtki gnostilist süsteemi, mis pärineks oma arenenud kujul varasemast ajast kui II sajandist. ${ }^{235}$

McLachlan Wilsoni toodud argumentidega peab üldiselt nõustuma. Põhiliseks vastuargumendiks eelkristlikule gnoosisele on asjaolu, et me ei saa ühtki gnostilist sekti ega teksti dateerida eelkristliku ajaga. Schmithals arvab, et gnostiliste tekstide kirjapanekule võis eelneda nende suulise tradeerimise faas ${ }^{236}$, kuid seda ei saa tõestada. Ühesõnaga - jääb küll avatuks teoreetiline võimalus, et gnoosis võis mingil kujul juba eelkristlikul ajal eksisteerida, kuid seda ei ole võimalik tõestada.

\section{Argumendid gnoosise olemasolu kasuks I sajandil pärast Kristuse sündimist}

Erinevalt gnoosise eelkristlikust päritolust on aga alust väita, et gnoosis eksisteeris kindlasti juba I kristlikul sajandil. Selle poolt võib tuua järgmised argumendid:

1) manda usund eksisteeris juba I sajandil $\mathrm{pKr}$;

2) Siimon Nõid elas ja tegutses Samaarias juba I sajandil pKr;

3) on kindel, et vähemalt Corpus Paulinumi hilisemates kirjades (pastoraalkirjad)

leiduvad eksiõpetused, mille üle seal polemiseeritakse, esindavad mingit gnoosise varast vormi; needki kirjad pärinevad I sajandist.

\footnotetext{
234 Quispel, G. Gnosis, 416 jj. 
Seepärast on käesoleva artikli autor nõus Schenke ja Theißeniga, kui nad väidavad, et gnoosis on umbes sama vana kui ristiusk. Äärmisel juhul on ta tekkinud vaid vahetult enne ristiusku, kuid seda pole võimalik tõestada. Gnoosise tekkimine ristiusust sõltumatult on aga ilmne seetõttu, et vanimates meile teadaolevates gnostilistes süsteemides (mandalased, simoniaanid) puudub kristlik aines, ja ka seetõttu, et gnoosise ja kristluse fenomenoloogilised alusstruktuurid on erinevad. ${ }^{237}$ Viimane tõsiasi ei lase gnoosise päritolu kristlusest otsida, aga kuna gnoosis on tekkinud ristiusuga enam-vähem ühel ajal ja tal on ristiusuga kokkupuuteid, siis on ka gnoosise varasem ajalugu osa Uue Testamendi kaasajast ning selle uurimine peaks olema oluline ka Uue Testamendi teaduse jaoks.

237 Quispel, G. Gnosis als Weltreligion. Zürich, 1951, 26.

\section{ORIGIN OF GNOSIS}

\section{Jaan LAHE}

Gnosticism is salvation religion that spread similarly to Christianity in the Mediterranean area but its origin is much debated starting from the ancient authors. It was supposed that the roots of Gnosis are in ancient Grecian philosophy or even in the teaching of the legendary Witch of Simeon. At the same time paradoxically the teaching was considered to be Christian heresy. Followers of Gnosticism considered themselves Christians but not all of them. The idea that Gnosticism is a branch of Christian teaching developed by ancient scholars was widely accepted in modern theology. It was at the end of the 19th century that the German school of religion history created a theory that Gnosis and Christianity had developed independently.

H. J. Schoeps and R. Haardt divided the modern understanding of the origin of Gnosis into three groups: ${ }^{1}$ theories that consider its roots to be found in Ancient Grecian philosophy and religious systems of mystic theology; ${ }^{2}$ theories believing that Gnosis can be traced in various Middle Eastern cults (Mesopotamian, Egyptian and Iranian); ${ }^{3}$ theories that support its origin in Jewish surroundings. Besides there are a few men of learning who consider Gnosis to be a derivate of Christianity. The problem remains under discussion and each theory has pro and contra arguments. However, it is widely accepted that the origin of Gnosis cannot be reduced (back) to any single religious doctrine. Various religious teachings of the Mediterranean area and ancient Grecian philosophy have influenced its genesis. It has been pointed out and stressed that some elements of Gnosis have common features with Jewish beliefs that support the hypothesis of its genesis and original spreading in the Jewish environment open to foreign influences. Many sources support the fact of the existence of such intellectual circles in the Hellenic world and during the Roman empire. We cannot deny the influence of various cults (Mesopotamian, 
Iranian, Judaism) on the development of Gnosis but its origination must be independent. The "mental structure" of Gnosis stands clearly on its own feet and it is not simply a mixture of borrowed religious and philosophical elements. This is why the understanding of R. Bultmann and H. Jonas has gathered many supporters. They stress that Gnosis is an original understanding of the world system and world view with strong dualism between material and mental with denial of the material. Motives borrowed from other beliefs can be considered to be "bricks" or resources in expressing the very special world view and gnosiology.

Although some motives and elements of Gnosis lead us back to the preChristian period, there is no approval of a solid system of it before Christ. This is why the majority of scholars agree that Gnosis has come into being independently but approximately at the sama time as Christianity. 